Article

\title{
Identification of Insulin-Like Growth Factor-I Receptor (IGF-IR) Gene Promoter-Binding Proteins in Estrogen Receptor (ER)-Positive and ER-Depleted Breast Cancer Cells
}

\author{
Rive Sarfstein ${ }^{1}$, Antonino Belfiore ${ }^{2}$ and Haim Werner ${ }^{1, *}$
}

1 Department of Human Molecular Genetics and Biochemistry, Sackler School of Medicine, Tel Aviv University, Tel Aviv 69978, Israel; E-Mail: rives@post.tau.ac.il

2 Department of Clinical and Experimental Medicine, University Magna Graecia of Catanzaro, Catanzaro 88100, Italy; E-Mail: belfiore@unicz.it

* Author to whom correspondence should be addressed: E-Mail: hwerner@post.tau.ac.il; Tel.: +972-3-6408542; Fax: +972-3-6406087.

Received: 23 February 2010 / Accepted: 19 March 2010 / Published: 25 March 2010

\begin{abstract}
The insulin-like growth factor I receptor (IGF-IR) has been implicated in the etiology of breast cancer. Overexpression of the IGF-IR gene is a typical feature of most primary breast cancers, whereas low IGF-IR levels are seen at advanced stages. Hence, evaluation of IGF-IR levels might be important for assessing prognosis. In the present study, we employed a proteomic approach based on DNA affinity chromatography followed either by mass spectroscopy (MS) or Western blot analysis to identify transcription factors that may associate with the IGF-IR promoter in estrogen receptor (ER)-positive and ER-depleted breast cancer cells. A biotinylated IGF-IR promoter fragment was bound to streptavidin magnetic beads and incubated with nuclear extracts of breast cancer cells. IGF-IR promoter-binding proteins were eluted with high salt and analyzed by MS and Western blots. Among the proteins that were found to bind to the IGF-IR promoter we identified zinc finger transcription factors Sp1 and KLF6, ER- $\alpha$, p53, c-jun, and poly (ADP-ribosylation) polymerase. Furthermore, chromatin immuneprecipitation (ChIP) analysis confirmed the direct in vivo binding of some of these transcription factors to IGF-IR promoter DNA. The functional relevance of binding data was assessed by cotransfection experiments with specific expression vectors along with an IGF-IR promoter reporter. In summary, we identified nuclear proteins that are potentially
\end{abstract}


responsible for the differential expression of the IGF-IR gene in ER-positive and ERdepleted breast cancer cells.

Keywords: transcription factors; estrogen receptor; insulin-like growth factor I receptor promoter; biomarkers; breast cancer

Abbreviations: IGF-IR: Insulin-like growth factor I receptor; ER: Estrogen receptor

\section{Introduction}

The insulin-like growth factors, IGF-I and IGF-II, are mitogenic polypeptides with important roles in cell growth and differentiation [1]. The biological activities of IGF-I and IGF-II are mediated by the IGF-I receptor (IGF-IR) and are modulated by a family of IGF-binding proteins (IGFBPs) that control ligand bioavailability [2-4]. The IGF-IR is essential for normal cell cycle progression and has a crucial role in tumor growth and metastasis development. Ligand-mediated activation of the IGF-IR tyrosine kinase domain leads to mitogenic and antiapoptotic effects in multiple cells and cancer-derived cell lines [5]. In the specific context of breast tumorigenesis, the IGF-IR is overexpressed in most primary tumors [4]. In addition, and consistent with its potent antiapoptotic role, IGF-IR-null cells do not undergo transformation when exposed to different oncogenes [6,7]. On the other hand, inhibition of IGF-IR signaling by IGF-IR antibodies, antisense oligonucleotides, IGF-BPs, or specific IGF-IR kinase inhibitors results in reduced cell proliferation and cancer progression in vivo and in vitro [8-14]. Furthermore, epidemiological studies revealed that high levels of circulating IGF-I are linked to an increased risk of developing breast cancer in premenopausal women $[15,16]$.

Regulation of IGF-IR gene expression is mainly attained at the transcription level. The IGF-IR promoter is a TATA-less, CCAAT-less, highly GC-rich, 'initiator'-type of promoter. IGF-IR gene transcription is dependent on a number of stimulatory zinc-finger nuclear proteins, including Sp1 [17] and KLF6 [18]. In addition, IGF-IR gene transcription is negatively regulated by several tumor suppressors, including BRCA1, p53/p63/p73, the von Hippel-Lindau protein (VHL), and the Wilms' protein-1 (WT1) [19-25]. Interactions between stimulatory and inhibitory transcription factors play an important role in IGF-IR gene regulation and, therefore, were postulated to have a major impact on the proliferative status of the cell. The molecular mechanisms and specific transcription factors responsible for regulating IGF-IR gene expression in breast cancer cells, however, have not yet been identified.

The IGF-I and estrogen signaling systems were shown to act in a synergistic fashion in breast epithelial cells [25]. Estrogens regulate IGF-I signaling and the expression of several members of the IGF system [25-31]. Moreover, activation of estrogen receptor- $\alpha(E R \alpha)$ by estrogens induces a physical interaction between ER $\alpha$ and IGF-IR [32] that results in activation and phosphorylation of IGF-IR and downstream signaling molecules [33-36]. The aim of this study was to identify the collections of IGF-IR promoter-binding transcription factors in ER-positive and ER-depleted breast cancer cells. Using DNA affinity chromatography, mass spectroscopy (MS), and Western blot analyses, we identified a series of known and previously unidentified transcription factors that 
specifically bind to the IGF-IR promoter in either cell type. The ability of selected proteins to bind and transactivate the IGF-IR promoter was confirmed by chromatin immunoprecipitation (ChIP) and transient transfection assays. In addition, we identified a number of non-DNA sequence-specific nuclear proteins that are probably involved in IGF-IR gene regulation. Identification of differentially expressed IGF-IR promoter-binding and non-binding transcription factors may help elucidate the mechanisms responsible for the differential expression of the IGF-IR gene in ER-positive and ERdepleted breast cancer cells.

\section{Material and Methods}

\subsection{Cell Cultures}

Human breast cancer-derived MCF7 cells [(ER-positive), American Type Culture Collection, Manassas, VA, USA] were grown in Dulbecco's modified Eagle's medium (DMEM) supplemented with $10 \%$ fetal bovine serum (FBS), $2 \mathrm{mM}$ glutamine, $50 \mu \mathrm{g} / \mathrm{mL}$ gentamicin sulfate, and $5.6 \mathrm{mg} / \mathrm{L}$ fungizone (Sigma-Aldrich Co., St. Louis, MO, USA). The C4.12.5 cell line was derived by clonal selection of MCF7 cells that were grown in the absence of estrogen for nine months [37]. C4.12.5 cells were maintained in phenol red-free DMEM with 10\% charcoal/dextran-treated FBS, 2 mM glutamine, and antibiotics. The C4.12.5 cell line was provided by Dr. Wade V. Welshons (University of Missouri, Columbia, MO, USA). Cells were incubated at $37^{\circ} \mathrm{C}$ in a humidified atmosphere containing $5 \% \mathrm{CO}_{2}$.

\subsection{PCR and DNA Affinity Chromatography of the IGF-IR Promoter}

For DNA affinity chromatography, a 511-bp human proximal IGF-IR promoter fragment extending from nucleotides -458 to +53 was labeled using a 5'-biotinylated antisense primer. This fragment includes most of the proximal 5'-flanking region and comprises the 'initiator' motif from which transcription starts in vivo (Nucleotide 1) (Figure 1).

Primer sequences were derived from genomic IGF-IR clone \#R73P2 [38] as follows: sense, 5'CTTTCCAGCCGCGCTGTTGTTG-3'; antisense, 5'-(Biotin)-GGTAAACAAGAGCCCCAGCCTC-3'. PCR was performed using the TermalAce ${ }^{\mathrm{TM}}$ DNA Polymerase reagent (InVitrogen, Carlsbad, CA, USA). The biotinylated PCR product was bound to streptavidin magnetic beads (Dynabeads ${ }^{\circledR} \mathrm{M}-270$ Streptavidin; Dynak Biotech ASA, Oslo, Norway), and incubated with nuclear extracts of MCF7 or C4.12.5 cells in the presence of double stranded poly dI-dC (Amersham Pharmacia Biotech, Piscataway, NJ, USA). Following high-salt elution, specifically-bound proteins were resolved on $10 \%$ SDS-PAGE gels and visualized by silver staining (Figure 2). Gel slices were then submitted for MS analysis at the Smoler Proteomics Center (Technion-Israel Institute of Technology, Haifa, Israel) or analyzed by Western blotting as described below. 
Figure 1. IGF-IR promoter. (A) Schematic representation of the IGF-IR promoter region [5]. The initiator (INR) element is denoted by an arrow. The coding region, starting with the AUG codon, is shown in gray. The translation start site is denoted by a dashed arrow. The 5'-flanking region is denoted by a black bar, and the 5'-untranslated region (UTR) is represented by a dotted bar. The location of primers (P\#1 and $\mathrm{P} \# 2$ ), employed to amplify the proximal promoter is indicated. (B) PCR amplification of the human IGF-IR promoter. The PCR reaction was performed using a biotinylated antisense primer, as described under Materials and Methods section, and $4 \mu \mathrm{L}$ of the biotinylated PCR product was loaded on a $1 \%$ agarose gel. A PCR reaction without DNA served as negative control. A 100-bp DNA ladder was used as a M.W. marker.
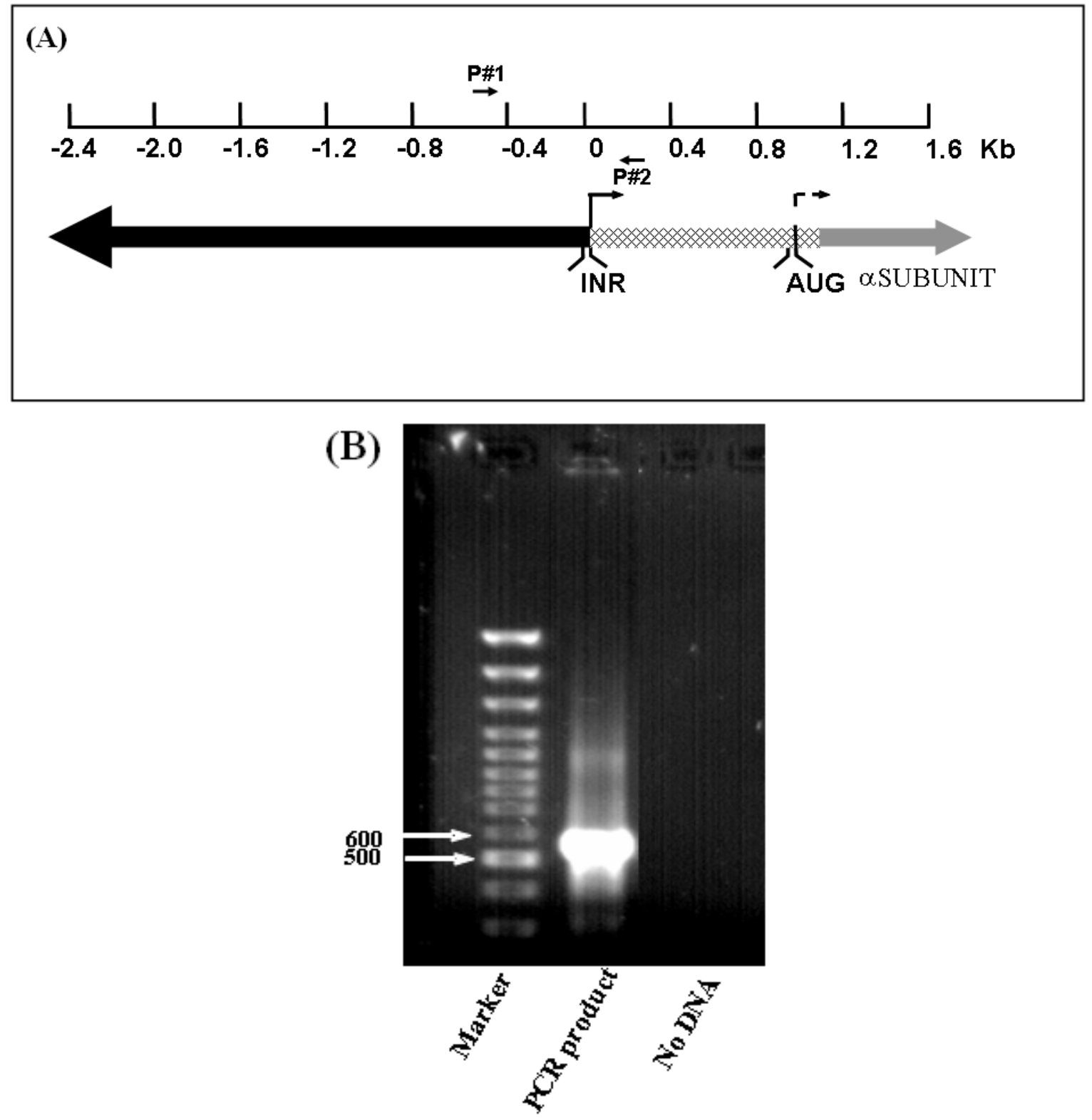
Figure 2. Silver staining of IGF-IR promoter-bound proteins identified by DNA affinity chromatography. Nuclear extracts of MCF7 cells were prepared as described under Materials and Methods Section. Proteins bound to IGF-IR promoter DNA (10 $\mu \mathrm{g})$ were electrophoresed through 10\% SDS-PAGE, fixed, and stained with silver (Bio-Rad, Hercules, CA, USA). Lane 1, M.W. marker; lane 2, starting material (MCF7 nuclear extract, $4.2 \mu \mathrm{g}$ ); lane 3, unbound material (MCF7 nuclear extract that did not bind to DNA, $4.2 \mu \mathrm{g}$ ); lane 4, eluted material bound to Biotin-520 bp (MCF7 nuclear proteins that bound to IGF-IR promoter, $10 \mu \mathrm{g}$ ); and lane 5, negative control (MCF7 nuclear proteins bound to strepavidin magnetic beads, $10 \mu \mathrm{g}$ ).

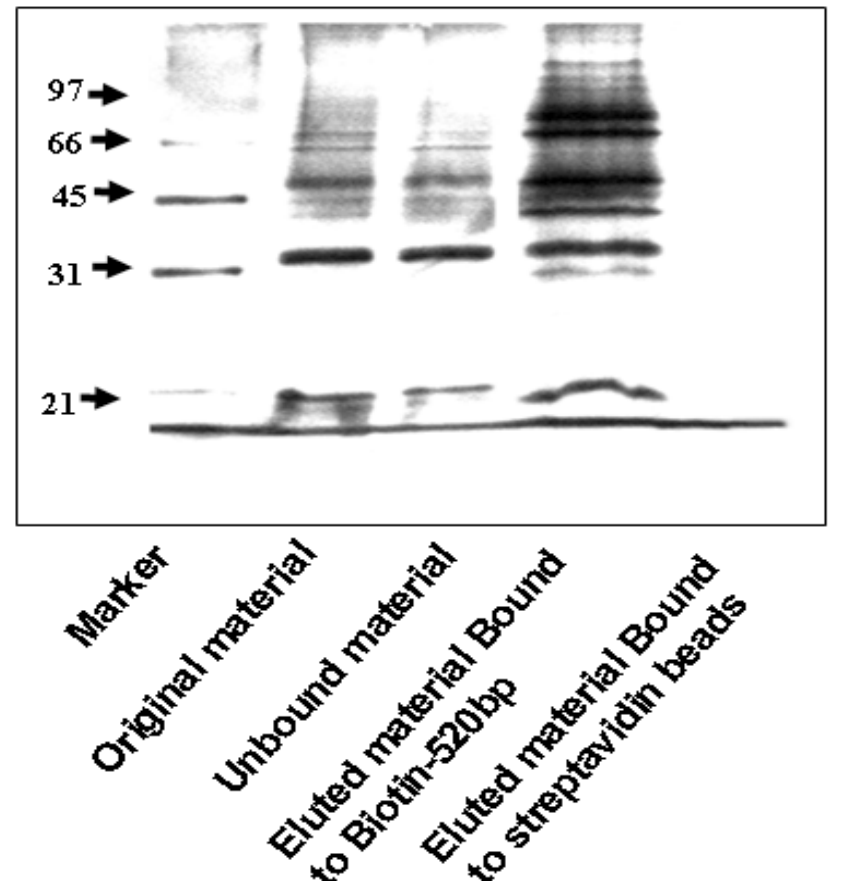

\subsection{Gel Slices Proteolysis and Mass Spectroscopy Analysis}

The gel slices containing the specific DNA-bound proteins were reduced with $10 \mathrm{mM}$ DTT, incubated at $60{ }^{\circ} \mathrm{C}$ for $30 \mathrm{~min}$, carboxyamidomethylated with $40 \mathrm{mM}$ iodoacetamide at room temperature for $30 \mathrm{~min}$, and trypsinized overnight at $37^{\circ} \mathrm{C}$ [modified trypsin (Promega)] at a 1:100 enzyme-to-substrate ratio. The tryptic peptides were resolved by reverse-phase chromatography on $0.075 \times 200-\mathrm{mm}$ fused silica capillaries (J\&W, Wilmington, DE, USA) packed with Reprosil reversed phase material (Dr Maisch GmbH, Germany). The peptides were eluted with a linear 90 min gradient from 5 to $45 \%$ acetonitrile containing $0.1 \%$ formic acid, followed by a wash of $95 \%$ acetonitrile for 15 min. The flow rate was $0.25 \mu \mathrm{l} / \mathrm{min}$ and the peptides were electrosprayed into an ion-trap mass spectrometer (Orbitrap, Thermo Fisher Scientific Inc., USA). MS was performed in a positive mode using repetitively full MS scans followed by collision induced dissociation (CID) of the 7 most dominant ions selected from the first MS scan. The MS data was clustered and analyzed using the Sequest software (Finnigan, San Jose, CA, USA) and Pep-Miner [39] searching against International Protein Index (IPI) protein IDs (part of the NR-NCBI database). 


\subsection{Cell Fractionation}

Whole cell extracts were prepared by lysing cells in a buffer containing protease inhibitors, as described previously [20]. To prepare cytosolic and nuclear extracts, cells were washed with ice-cold phosphate-buffered saline (PBS), centrifuged, and the pellet was resuspended in buffer A [10 mM Hepes (pH 7.9), $1.5 \mathrm{mM} \mathrm{MgCl} 2,10 \mathrm{mM} \mathrm{KCl,} 0.1 \mathrm{mM}$ EDTA, $0.1 \mathrm{mM}$ EGTA, $1 \mathrm{mM}$ dithiothreitol, $2 \mu \mathrm{g} / \mathrm{mL}$ aprotinin, $1 \mathrm{mM}$ ortovanadate, $2 \mu \mathrm{g} / \mathrm{mL}$ leupeptin, $4 \mathrm{mM}$ pyrophosphate, $2 \mu \mathrm{g} / \mathrm{mL}$ pepstatin, and $1 \mathrm{mM}$ PMSF] and incubated for $30 \mathrm{~min}$ on ice. IGEPAL (CA-630, Sigma-Aldrich Co.) was then added to a final concentration of $3 \%$, vortexed, and centrifuged $(14,000 \mathrm{rpm}, 30 \mathrm{sec})$, after which the supernatant containing the cytosolic fraction was saved at $-70{ }^{\circ} \mathrm{C}$. Buffer $\mathrm{C}$ [20 $\mathrm{mM}$ Hepes, $420 \mathrm{mM}$ $\mathrm{NaCl}, 1 \mathrm{mM}$ EDTA, $1 \mathrm{mM}$ EGTA, and protease inhibitors] was added to the nuclei-containing pellet, incubated for $30 \mathrm{~min}$ at room temperature, and spun at $14,000 \mathrm{rpm}$ for $5 \mathrm{~min}$. The supernatant containing the nuclear extract was frozen at $-70{ }^{\circ} \mathrm{C}$. Protein concentrations were determined with the Bradford reagent (Bio-Rad, Hercules, CA, USA) using bovine serum albumin (BSA) as a standard.

\subsection{Western Immunoblots}

Samples were electrophoresed through $12 \%, 10 \%$, or $7.5 \%$ SDS-PAGE gels, followed by blotting of the proteins onto nitrocellulose membranes. After blocking with either skim milk or 3\% BSA, the blots were incubated overnight with the antibodies listed below, washed and incubated with the appropriate horseradish peroxidase (HRP)-conjugated secondary antibody. Antibodies against BRCA1 (C-20), TOPOII (C-15), MET (C-28), p120 (H-90), androgen receptor [(AR), N-20], IGF-IR $\beta$-subunit (C-20), Sp1 (PEP2), TCF3A (M-20), c-fos (4), ER $\alpha$ (MC-20), WT1 (C-19), KLF6 (R-173), lamin A/C (636), Smad2/3 (FL-425), c-Myc (9E10), p63 (4A4), E2F1 (KH95), LEF1 (C-19), TCF1A (C-21), p53 (mixture of DO-1 and Pab 1801), GSK3 $\beta$ (11B7), phospho c-jun (KM-1), cyclin D (H295), cyclin G (F-5), histone1 (FL-219), $\beta$-catenin (E-5), p300 (C-20), BRCA2 (H-300), TLE-1 (M-101), p21 (C-19), normal mouse IgG [NMS (SC-2025)], and normal rabbit IgG [NRS (SC-2027)] were purchased from Santa Cruz Biotechnology (Santa Cruz, CA, USA). An antibody against tubulin (Clone: B-5-1-2) was purchased from Sigma-Aldrich Co. Anti IRS-1 was kindly provided by Dr. Hagit Eldar-Finkelman (Tel Aviv University). Antibodies against poly ADP ribose polymerase [(PARP); 9542 and 9532], phospho-IGF-IR (3024), Foxo1 (9462), and phospho-Smad2 (3101) were obtained from Cell Signaling Technology (Beverly, MA, USA). In addition, the following antibodies were used: p73 (Ab-1; Oncogene Research Products, San Diego, CA, USA), c-jun (610326; BD Transduction Laboratories, Franklin Lakes, NJ, USA), APC (OP47L; Calbiochem, San Diego, CA, USA) and hemagglutinin (HA-11; Berkeley Antibody Company, Richmond, CA, USA). The secondary antibodies were HRP-conjugated bovine (1:500) or donkey (1:500) anti-goat IgG (both from Santa Cruz Biotechnology), goat anti-rabbit $\operatorname{IgG}(1: 50,000)$ and donkey anti-mouse $\operatorname{IgG}(1: 25,000$; Jackson ImmunoResearch Laboratories, West Grove, PA, USA). Proteins were detected using the SuperSignal West PicoChemiluminescent Substrate (Pierce, Rockford, IL, USA). 


\subsection{Chromatin Immunoprecipitation Assays}

The ChIP assays were performed as described previously [40]. Briefly, MCF7 cells were crosslinked with $1 \%$ formaldehyde at $37{ }^{\circ} \mathrm{C}$ for $10 \mathrm{~min}$. Cells were rinsed with ice-cold PBS and centrifuged. The pellet was then resuspended in lysis buffer (1\% SDS, $10 \mathrm{mM}$ EDTA, $50 \mathrm{mM}$ Tris$\mathrm{HCl}, \mathrm{pH} 8.1$ and protease inhibitor mixture: $1 \mathrm{mM}$ PMSF, $1 \mu \mathrm{g} / \mathrm{mL}$ aprotinin and $1 \mu \mathrm{g} / \mathrm{ml}$ pepstatin A) and sonicated for $3 \mathrm{~min}$. The supernatant fraction was immunoprecipitated with anti-PARP, anti-cjun, anti-Sp1, anti-KLF6, anti-HA, and NRS or NMS for $18 \mathrm{~h}$ at $4{ }^{\circ} \mathrm{C}$. The next day, Protein A/G plus agarose beads (SC-20003, Santa Cruz Biotechnology) was added for one hour at $4{ }^{\circ} \mathrm{C}$. Immunoprecipitates were electrophoresed and immunoblotted as described under Western immunoblots. For PCR analysis of antibody-immunoprecipitated chromatin, a set of primers encompassing the IGF-IR proximal promoter region, sense, 3'-CCAGCCGCGCTGTTGTTG-5', antisense: 3-CCAGCCGCGCTGTTGTTG-5, and Thermolace ${ }^{\mathrm{TM}}$ DNA polymerase kit were used.

\subsection{DNA Transfections}

For transient cotransfection experiments an IGF-IR promoter luciferase reporter construct including $476 \mathrm{bp}$ of 5'-flanking and $640 \mathrm{bp}$ of 5'-untranslated regions of the IGF-IR gene $[\mathrm{p}(-476 /+640)$ luciferase (LUC)] was employed [41,42]. An expression vector encoding c-jun (RSV-c-jun) was provided by Dr. Lili Vardimon (Tel Aviv University). An HA-HMGA1 expression vector (in pcDNA3) was provided by Dr. G. Manfioletti (University of Trieste, Italy) [43]. A KLF6 expression vector (pCI-neo-KLF6) was provided by Dr. Scott L. Friedman (Mount Sinai School of Medicine, New York, USA). The E2F1 expression vector, pcDNA-I-E2F-1, was previously described [44]. Cells were seeded in six-well plates the day before transfection and cotransfected with $1 \mu \mathrm{g}$ of the IGF-IR promoter reporter along with $1 \mu \mathrm{g}$ of the E2F1 expression plasmid (or empty pCDNA3), or $2 \mu \mathrm{g}$ of the HA-HMGA1 (or empty pCDNA3), or $2 \mu \mathrm{g}$ of the pCI-neo-KLF6 (or empty pCI-neo) using the Jet-PEI (Polyplus, Illkirch, France) transfection reagent. Cells were harvested $48 \mathrm{~h}$ after transfection, and luciferase activity was measured as previously described [41]. Promoter activities were expressed as luciferase values normalized to protein concentrations. Protein content was determined using the Bradford reagent (Bio-Rad, Hercules, CA, USA) using BSA as a standard.

\section{Results}

\subsection{ER and IGF-IR Expression in MCF7 and C4.12.5 Cells}

The involvement of the IGF-IR in breast cancer development has been well established. To address the potential regulation of IGF-IR expression during breast cancer progression, we measured in initial experiments the levels of total and phospho-IGF-IR (pIGF-IR) in syngeneic cell lines representing different stages of the disease. For this purpose, we employed the human breast cancer-derived MCF7 (ER-positive) and MCF7-derived C4.12.5 (ER-depleted) cell lines. C4.12.5 cells were generated by clonal selection of MCF7 cells that were maintained in estrogen-free conditions for nine months [37]. Although C4.12.5 cells exhibited some variability in ER expression, the passages used in the present 
study displayed consistently low levels of ER $\alpha$ ( $\sim 59 \%$ of the ER $\alpha$ levels in MCF7 cells). Western blots using anti-IGF-IR $\beta$-subunit and anti-pIGF-IR antibodies showed that both total IGF-IR and pIGF-IR levels were significantly reduced in C4.12.5, in comparison to, MCF7 cells (76\% for IGF-IR and $30 \%$ for pIGF-IR) (Figure 3). These results corroborate previous observations $[40,45]$.

Figure 3. IGF-IR and ER $\alpha$ expression in MCF7 and C4.12.5 breast cancer cell lines. MCF7 and C4.12.5 cells were lysed as described under Materials and Methods. Cellular extracts $(80 \mu \mathrm{g})$ were electrophoresed through 10\% SDS-PAGE, transferred to nitrocellulose membranes, and blotted with anti-total IGF-IR- $\beta$, anti-pIGF-IR, and anti-ER $\alpha$. Blots were then blotted with a tubulin antibody as a loading control.

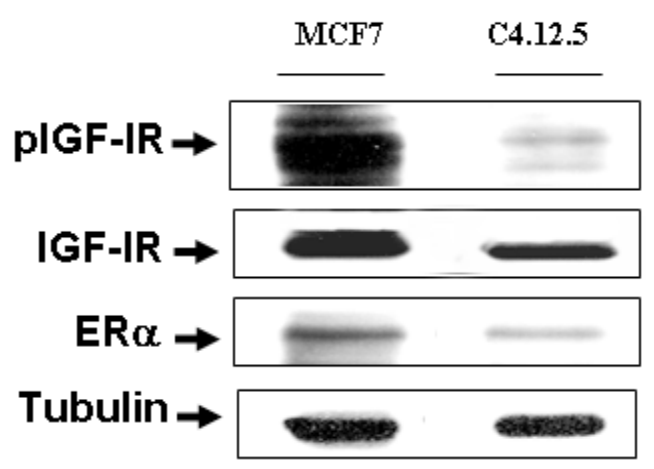

\subsection{DNA Affinity Chromatography}

The MCF7 and C4.12.5 cell lines were employed to identify the sets of IGF-IR promoter-binding proteins that may be involved in IGF-IR transcription and that are responsible for the differential expression of the gene at different stages of the disease. The rationale for these studies was the fact that regulation at the transcription level has been identified as a major control step in IGF-IR regulation [46]. To this end, we used a proteomic approach based on DNA affinity chromatography followed either by MS or Western blot analyses using antibodies against previously identified or novel IGF-IR promoterbinding proteins. The basis for selecting this specific fragment was the fact that previous studies have shown that this region is responsible for most of the promoter activity. Nuclear extracts of MCF7 and C4.12.5 cells were incubated with the PCR-amplified, biotin-labeled IGF-IR proximal promoter DNA probe, after which DNA-protein complexes were adsorbed to streptavidin beads. Bound proteins were eluted with high-salt buffer and concentrated by centrifugation at reduced pressure. The eluted material was electrophoresed through 10\% SDS-PAGE and proteins were visualized by silver staining (Figure 2). A number of bands were seen in the eluted material (lane 4) whereas no proteins were detected in eluates of lysates incubated with strepavidin magnetic beads alone (lane 5). Silver stained gels were cut into slices and the specific DNA-bound proteins were analyzed by MS.

\subsection{MS Analysis}

MS analysis of DNA affinity chromatography-purified proteins identified a number of previously reported and several novel IGF-IR promoter binding proteins. The proteins identified were categorized using the Gi (gene index) identification tool, coverage (percentage of amino acids covered by the 
identified peptide), and source (Table 1). The specific proteins bound to the IGF-IR promoter were classified based on cellular localization and biological function (Table 2). Most of the proteins were localized in the nucleus, but some of them were found also in the cytoplasm as well as in the plasma membrane. Furthermore, Table 2 illustrates the variety of biological processes associated with the identified IGF-IR promoter-binding transcription factors in ER-positive and ER-depleted breast cancer cells. Out of 91 proteins identified by MS, 6 correspond to cytoskeleton-associated proteins, 6 are involved in transcription, regulation of nucleobase, nucleoside and nucleic acid metabolism, 2 in nuclear stability, chromatin structure, cycle control, and gene expression, 20 in DNA repair, breaking, replication, and cell death, 24 in RNA splicing and processing, and translation, and 33 in other functions, including proliferation, apoptosis, and proteosomal degradation.

Table 1. IGF-IR promoter-binding proteins identified by MS in MCF7 and C4.12.5 cells.

\begin{tabular}{|c|c|c|c|c|}
\hline & Protein Name & Coverage & Coverage & Source \\
\hline & & MCF7 & C4.12.5 & \\
\hline 4760598 & Adenylate kinase isozyme 2 & 4 & - & Mus musculus \\
\hline 61743954 & AHNAK nucleoprotein isoform 1 & 1 & 3 & Homo sapiens \\
\hline 1061128 & Anpg & 25 & 21 & Homo sapiens \\
\hline 5453541 & Anterior gradient 2 homolog & 26 & - & Homo sapiens \\
\hline 6753086 & Apurinic/apyrimidinic endonuclease 1 & 8 & - & Mus musculus \\
\hline 10947139 & Arginase, type I & - & 3 & Homo sapiens \\
\hline 6680748 & $\begin{array}{l}\text { ATP synthase, } \mathrm{H}^{+} \text {transporting, mitochondrial F1 } \\
\text { complex, alpha subunit, isoform } 1\end{array}$ & 3 & 7 & Mus musculus \\
\hline 10863945 & ATP-dependent DNA helicase II & 20 & 28 & Homo sapiens \\
\hline 4503841 & ATP-dependent DNA helicase II, 70 kDa subunit & 22 & 28 & Homo sapiens \\
\hline 1040689 & $\begin{array}{l}\text { ATP-dependent DNA helicase Q1 (DNA-dependent } \\
\text { ATPase Q1) }\end{array}$ & - & 4 & Homo sapiens \\
\hline 42740907 & Clusterin isoform 2 & - & 8 & Homo sapiens \\
\hline 22208854 & $\begin{array}{l}\text { Cytidine monophospho-N-acetylneuraminic acid } \\
\text { synthetase }\end{array}$ & 3 & 3 & Mus musculus \\
\hline 4557515 & Damage-specific DNA binding protein $2(48 \mathrm{kD})$ & 6 & 18 & Homo sapiens \\
\hline 45476309 & $\begin{array}{l}\text { Damage-specific DNA binding protein } 2 \text { splicing variant } \\
\text { D4 }\end{array}$ & 7 & 13 & Homo sapiens \\
\hline 4758138 & DEAD (Asp-Glu-Ala-Asp) box polypeptide 5 & 15 & 13 & Homo sapiens \\
\hline 506756 & Desmoyokin & - & 6 & \\
\hline 1706481 & DNA ligase III & 23 & 37 & Homo sapiens \\
\hline 11225260 & DNA topoisomerase I & 10 & 11 & Homo sapiens \\
\hline 347019 & DnaK-type molecular chaperone hsp72-ps1 & 8 & 10 & Rattus norvegicus \\
\hline 1722884 & DNA-repair protein complementing XP-C cells & - & 6 & $\begin{array}{l}\text { Drosophila } \\
\text { melanogaster }\end{array}$ \\
\hline 38201714 & ELAV-like 1 & 10 & - & Homo sapiens \\
\hline 4503471 & Eukaryotic translation elongation factor $1 \alpha 1$ & 6 & 2 & Homo sapiens \\
\hline 4503477 & Eukaryotic translation elongation factor $1 \beta 2$ & 7 & - & Homo sapiens \\
\hline 25453472 & Eukaryotic translation elongation factor $1 \delta$ isoform 2 & 22 & - & Homo sapiens \\
\hline
\end{tabular}


Table 1. Cont.

\begin{tabular}{|c|c|c|c|c|}
\hline 110625979 & Eukaryotic translation elongation factor $1 \gamma$ & 6 & - & Mus musculus \\
\hline 37078458 & $\begin{array}{l}\text { Far upstream element-binding protein } 1 \text { (FUSE-binding } \\
\text { protein 1) }\end{array}$ & 11 & 13 & Mus musculus \\
\hline 27806887 & Fusion (involved in $\mathrm{t}(12 ; 16)$ in malignant liposarcoma) & 5 & _- & Bos taurus \\
\hline 7669492 & Glyceraldehyde-3-phosphate dehydrogenase & 9 & - & Mus musculus \\
\hline 74736618 & Grainyhead-like protein 2 homolog & - & 16 & Homo sapiens \\
\hline 51316135 & GTP-binding nuclear protein Ran, testis-specific isoform & 10 & - & Rattus norvegicus \\
\hline 4504517 & Heat shock $27 \mathrm{kDa}$ protein 1 & 33 & - & Homo sapiens \\
\hline 2495339 & Heat shock $70 \mathrm{kDa}$ protein $1 \mathrm{~B}$ & 8 & 10 & Bos taurus \\
\hline 8393547 & Heterogeneous nuclear ribonucleoprotein A1 & 13 & 11 & Rattus norvegicus \\
\hline 14043072 & Heterogeneous nuclear ribonucleoprotein $\mathrm{A} 2 / \mathrm{B} 1$ isoform $\mathrm{B} 1$ & 19 & 10 & Homo sapiens \\
\hline 31559916 & Heterogeneous nuclear ribonucleoprotein A3 isoform a & 11 & 15 & Mus musculus \\
\hline 55956919 & Heterogeneous nuclear ribonucleoprotein $\mathrm{AB}$ isoform a & 9 & 3 & Homo sapiens \\
\hline 14249959 & Heterogeneous nuclear ribonucleoprotein C (C1/C2) & 10 & 2 & Homo sapiens \\
\hline 870747 & Heterogeneous nuclear ribonucleoprotein D (hnRNP D) & 11 & 22 & Homo sapiens \\
\hline 10946928 & Heterogeneous nuclear ribonucleoprotein $\mathrm{H} 1$ & 13 & 8 & Mus musculus \\
\hline 14141157 & Heterogeneous nuclear ribonucleoprotein $\mathrm{H} 3$ isoform a & 11 & - & Homo sapiens \\
\hline 13384620 & Heterogeneous nuclear ribonucleoprotein $\mathrm{K}$ & 23 & 10 & Mus musculus \\
\hline 133274 & Heterogeneous nuclear ribonucleoprotein L (hnRNP L) & 4 & 4 & Homo sapiens \\
\hline 14141152 & Heterogeneous nuclear ribonucleoprotein $\mathrm{M}$ isoform a & 15 & 18 & Homo sapiens \\
\hline 5031755 & Heterogeneous nuclear ribonucleoprotein $\mathrm{R}$ isoform 2 & 6 & 6 & Homo sapiens \\
\hline 8393536 & High mobility group box 2 & 14 & - & Rattus norvegicus \\
\hline 1568557 & Histone $\mathrm{H} 2 \mathrm{~B}$ & 19 & 12 & Homo sapiens \\
\hline 968888 & HMG-1 & 13 & - & Homo sapiens \\
\hline 32358 & HnRNP U protein & 11 & 9 & Homo sapiens \\
\hline 37183160 & HRPE773 & - & 29 & Homo sapiens \\
\hline 1040689 & Human Diff6, H5, CDC10 homologue, KIAA0097 & 6 & - & Homo sapiens \\
\hline 13385872 & Interleukin enhancer binding factor 2 & 8 & 13 & Mus musculus \\
\hline 4504865 & KH-type splicing regulatory protein (FUSE binding protein 2) & 6 & 8 & Homo sapiens \\
\hline 6453818 & Kinesin family member 22 & - & 20 & Homo sapiens \\
\hline 2055427 & KSRP & 5 & 26 & Homo sapiens \\
\hline 27436946 & Lamin $\mathrm{A} / \mathrm{C}$ isoform 1 precursor & 20 & 15 & Homo sapiens \\
\hline 5031877 & Lamin B1 & 8 & 21 & Homo sapiens \\
\hline 14149645 & Methyl CpG binding protein 2 & 4 & 4 & Mus musculus \\
\hline 1770458 & M-phase phosphoprotein 4 & 12 & 6 & Homo sapiens \\
\hline 4038587 & Mucin & - & 2 & Homo sapiens \\
\hline 55956788 & Nucleolin & 5 & 5 & Homo sapiens \\
\hline 58037163 & Nucleoporin 35 & 6 & - & Mus musculus \\
\hline 35119 & NuMA protein & - & 2 & Homo sapiens \\
\hline 1483131 & $\mathrm{p} 80$ protein & 3 & 3 & Homo sapiens \\
\hline 115497186 & Paraspeckle component 1 & 2 & 7 & Bos taurus \\
\hline 156523968 & Poly (ADP-ribose)polymerase & 32 & 36 & Homo sapiens \\
\hline 14141166 & Poly(rC)-binding protein 2 isoform $b$ & 20 & 9 & Homo sapiens \\
\hline
\end{tabular}


Table 1. Cont.

\begin{tabular}{llccl}
\hline 31543419 & Polynucleotide kinase 3 phosphatase & 13 & 11 & Homo sapiens \\
4506243 & Polypyrimidine tract-binding protein 1 isoform a & 8 & 10 & Homo sapiens \\
4502801 & Regulator of chromosome condensation (RCC1) & 12 & 10 & Homo sapiens \\
4506583 & Replication protein A1, 70kDa & 18 & 26 & Homo sapiens \\
4506585 & Replication protein A2, 32kDa & 7 & - & Homo sapiens \\
4506439 & Retinoblastoma binding protein 7 & 3 & - & Homo sapiens \\
15718687 & Ribosomal protein S3 & 23 & - & Homo sapiens \\
7159943 & RNA and export factor binding protein 1-II & 24 & 9 & Mus musculus \\
4757926 & RNA binding motif protein 39 isoform b & 3 & - & Homo sapiens \\
66346679 & SERPINE1 mRNA binding protein 1 isoform 1 & 9 & 9 & Homo sapiens \\
2440078 & SPIN protein & - & 4 & Homo sapiens \\
4826998 & Splicing factor proline/glutamine rich & 9 & 11 & Homo sapiens \\
5902076 & Splicing factor, arginine/serine-rich 1 isoform 1 & 4 & - & Homo sapiens \\
39930517 & Sterile alpha motif domain containing 1 & 11 & 17 & Homo sapiens \\
30088600 & Telomerase subunit EST1A & 1 & 1 & Homo sapiens \\
4507555 & Thymopoietin isoform alpha & 8 & 17 & Homo sapiens \\
4507401 & Transcription factor A, mitochondrial & 4 & - & Homo sapiens \\
14389309 & Tubulin alpha 6 & 6 & 12 & Homo sapiens \\
12963615 & Tubulin, beta 3 & 9 & 8 & Mus musculus \\
21361322 & Tubulin, beta 4 & 9 & 9 & Homo sapiens \\
1066004 & Typr II DNA topoisomerase beta isoform & - & 1 & Mus musculus \\
28077011 & Tyrosyl-DNA phodphodiesterase 1 & 4 & 4 & Mus musculus \\
4506387 & UV excision repair protein RAD23 homolog B & 4 & - & Homo sapiens \\
2632123 & Xeroderma Pigmentosum Group E Complementing protein & 7 & 17 & Homo sapiens \\
5454172 & X-ray repair cross complementing protein 1 & 9 & 12 & Homo sapiens \\
\hline & id & 5 & & \\
\hline
\end{tabular}

Gi: identification tool; Coverage: percentage of amino acids covered by the identified peptide $(\mathrm{n}=3$ independent analyses).

Table 2. Summary of functional categories of IGF-IR promoter-bound proteins identified by MS.

\begin{tabular}{|l|l|l|}
\hline Gene & $\begin{array}{l}\text { Subcellular } \\
\text { fraction }\end{array}$ & Function \\
\hline Cytoskeleton-associated proteins & & \\
\hline KIAA0097; Human Diff6 & $\begin{array}{l}\text { Cytoplasm } \\
\text { Nucleus }\end{array}$ & Microtubule associated protein. \\
\hline Kinesin family member 22 & Nucleus & Microtubule-dependent molecular motor. \\
\hline NuMA protein & Nucleus & Component of the mitotic spindle matrix. \\
\hline $\begin{array}{l}\text {-Tubulin } \alpha 6 \\
\text {-Tubulin, } \beta 3\end{array}$ & $\begin{array}{l}\text { Cytoplasm } \\
\text {-Tubulin, } \beta 4\end{array}$ & Rucleus \\
\hline
\end{tabular}


Table 2. Cont.

\begin{tabular}{|c|c|c|}
\hline $\begin{array}{l}\text { Factors involved in transcription, regulation of } \\
\text { nucleobase, nucleoside, nucleotide and nucleic } \\
\text { acid metabolism }\end{array}$ & & \\
\hline $\begin{array}{l}\text {-Elongation factor-1 (EF1) } \\
\text {-Eukaryotic translation elongation factor } 1 \beta 2 \\
\text {-Eukaryotic translation elongation factor } 1 \delta \\
\text { isoform } 2 \\
\text { - Eukaryotic translation elongation factor } 1 \gamma\end{array}$ & $\begin{array}{l}\text { Cytoplasm } \\
\text { Nucleus }\end{array}$ & $\begin{array}{l}\text { Involved in enzymatic delivery of aminoacyl tRNAs } \\
\text { to the ribosome. }\end{array}$ \\
\hline Poly(rC)-binding protein 2 isoform $b$ & $\begin{array}{l}\text { Cytoplasm } \\
\text { Nucleus }\end{array}$ & $\begin{array}{l}\text { RNA binding protein involved in regulation of } \\
\text { nucleobase, nucleoside, nucleotide and nucleic acid } \\
\text { metabolism. }\end{array}$ \\
\hline $\begin{array}{l}\text { Telomerase subunit EST1A } \\
\text { Alternative name: Chromosome } 17 \text { open reading } \\
\text { frame } 31 \\
\text { Estlp like protein A } \\
\text { Ever shorter telomeres } 1\end{array}$ & $\begin{array}{l}\text { Nucleus } \\
\text { Nucleolus }\end{array}$ & Telomere regulation. \\
\hline $\begin{array}{l}\text { Nuclear stability, chromatin structure, cycle } \\
\text { control, gene expression }\end{array}$ & & \\
\hline $\begin{array}{l}\text {-Lamin B1 } \\
\text {-Lamin A/C }\end{array}$ & Nucleus & $\begin{array}{l}\text { Nuclear stability, chromatin structure and gene } \\
\text { expression. }\end{array}$ \\
\hline $\begin{array}{l}\text { Proteins with a known function in DNA repair, } \\
\text { breaking, replication, transcription and cell } \\
\text { death }\end{array}$ & & \\
\hline Apurinic/apyrimidinic endonuclease 1 & Nucleus & DNA repair and redox regulatory activities. \\
\hline $\begin{array}{l}\text { ATP-dependent DNA helicase II, } 70 \mathrm{kDa} \\
\text { subunit } \\
\text { ATP-dependent }(80 \mathrm{kda})\end{array}$ & Nucleus & Repair of nonhomologous DNA ends. \\
\hline $\begin{array}{l}\text { ATP-dependent DNA helicase Q1 (DNA- } \\
\text { dependent ATPase }\end{array}$ & Nucleus & $\begin{array}{l}\text { Repair of UV-irradiated DNA damage or other } \\
\text { mutagens. }\end{array}$ \\
\hline $\begin{array}{l}\text { - Damage-specific DNA binding protein } \\
(127 \mathrm{kDa})-\mathrm{DDB} 1 \\
\text {-Damage-specific DNA binding protein } 2 \\
(48 \mathrm{kD}) \text { - DDB2 } \\
\text {-Damage-specific DNA binding protein } 2 \\
\text { splicing variant D4 }\end{array}$ & $\begin{array}{l}\text { Cytoplasm } \\
\text { Nucleus }\end{array}$ & Repair of UV-irradiated DNA damage. \\
\hline $\begin{array}{l}\text {-DNA Topoisomerase I } \\
\text {-DNA Topoisomerase II } \\
\text { - Tyrosyl-DNA phosphodiesterase } 1 \\
\end{array}$ & $\begin{array}{l}\text { Cytoplasm } \\
\text { Nucleus } \\
\text { Nucleoplasm }\end{array}$ & $\begin{array}{l}\text { Type I topoisomerase breaks single DNA strands, } \\
\text { whereas Type II topoisimerase breaks double } \\
\text { stranded DNA. }\end{array}$ \\
\hline $\begin{array}{l}\text {-High mobility group box } 2 \\
\text {-High Mobility Group Protein } 17 \text { (HMG17) - } \\
\text { chromosomal protein } \\
\text {-HMG1 }\end{array}$ & Nucleus & $\begin{array}{l}\text { DNA repair, recombination, replication, and } \\
\text { transcription. }\end{array}$ \\
\hline Histone 1,2 and 3 & Nucleus & $\begin{array}{l}\text { Play a central role in transcription regulation, DNA } \\
\text { repair, DNA replication and chromosomal stability. }\end{array}$ \\
\hline
\end{tabular}


Table 2. Cont.

\begin{tabular}{|c|c|c|}
\hline Poly (ADP-ribosylation) polymerase I-PARP-1 & Nucleus & $\begin{array}{l}\text { DNA repair, replication, transcription and cell } \\
\text { death. }\end{array}$ \\
\hline Polynucleotide kinase 3 phosphatase & Nucleus & $\begin{array}{l}\text { DNA repair following ionizing radiation or } \\
\text { oxidative damage. }\end{array}$ \\
\hline $\begin{array}{l}\text { Replication protein A1, 70kDa } \\
\text { Replication Protein A2, 32-KD; RPA2 }\end{array}$ & Nucleus & Replication, recombination and DNA repair. \\
\hline Ribosomal Protein S3; RPS3 & $\begin{array}{l}\text { Cytoplasm } \\
\text { Nucleus }\end{array}$ & DNA repair and apoptosis. \\
\hline $\begin{array}{l}\text { Xeroderma Pigmentosum Group E } \\
\text { Complementing protein } \\
\text { X-ray repair cross complementing protein } 1\end{array}$ & $\begin{array}{l}\text { Cytoplasm } \\
\text { Nucleus } \\
\text { Nucleus }\end{array}$ & $\begin{array}{l}\text { Involved in DNA repair. } \\
\text { Repair of single-strand DNA breaks. }\end{array}$ \\
\hline \multicolumn{3}{|l|}{$\begin{array}{l}\text { RNA slipicing, RNA processing, Transcription, } \\
\text { Translation and other functions }\end{array}$} \\
\hline $\begin{array}{l}\text {-Dead/H-box-5 } \\
\text {-RNA Helicase p68 }\end{array}$ & Nucleus & $\begin{array}{l}\text { Implicated in cellular processes involving alteration } \\
\text { of RNA secondary structure. }\end{array}$ \\
\hline ELAV-like 1 & $\begin{array}{l}\text { Cytoplasm } \\
\text { Nucleus }\end{array}$ & RNA-binding proteins. \\
\hline $\begin{array}{l}\text { Fusion (involved in } \mathrm{t}(12 ; 16) \text { in malignant } \\
\text { liposarcoma) }\end{array}$ & Nucleus & Plays a role in maintenance of genomic integrity. \\
\hline hnRNP U protein & $\begin{array}{l}\text { Cell surface } \\
\text { Nucleus }\end{array}$ & Binds to pre-mRNA. \\
\hline Interleukin enhancer binding factor 2 variant & $\begin{array}{l}\text { Nucleus } \\
\text { Nucleolus }\end{array}$ & $\begin{array}{l}\text { Regulates transcription of the IL } 2 \text { gene during T- } \\
\text { cell activation. }\end{array}$ \\
\hline Nucleolin & $\begin{array}{l}\text { Nucleus } \\
\text { Nucleolus }\end{array}$ & $\begin{array}{l}\text { The major nucleolar protein of growing eukaryotic } \\
\text { cells. }\end{array}$ \\
\hline RNA and export factor binding protein 1 & $\begin{array}{l}\text { Cytoplasm } \\
\text { Nucleus }\end{array}$ & Nuclear mRNA export pathway. \\
\hline RNA binding motif protein 39 isoform $b$ & Nucleus & $\begin{array}{l}\text { Transcriptional coactivator for steroid nuclear } \\
\text { receptors ESR1/ER } \alpha \text { and ESR2/ER- } \beta \text {, and } \\
\text { JUN/AP-1. }\end{array}$ \\
\hline $\begin{array}{l}\text {-Splicing factor, arginine/serine-rich } 1 \text { isoform } 1 \\
\text { - Splicing factor proline/glutamine rich }\end{array}$ & $\begin{array}{l}\text { Cytoplasm } \\
\text { Nucleus }\end{array}$ & Prevents exon skipping. \\
\hline \multicolumn{3}{|l|}{ Others } \\
\hline Adenylate kinase isozyme 2 & $\begin{array}{l}\text { Membrane } \\
\text { Microsomal } \\
\text { Mitochondria } \\
\text { Nucleus }\end{array}$ & Small ubiquitous enzyme. \\
\hline $\begin{array}{l}\text { Alkyladenine DNA glycosylase (AAG), also } \\
\text { known as 3-methyladenine DNA glycosylase, }\end{array}$ & Nucleus & Catalyzes the first step in base excision repair. \\
\hline Arginase, type I & Mitochondria & $\begin{array}{l}\text { Plays a role in the regulation of extra-urea cycle } \\
\text { arginine metabolism. }\end{array}$ \\
\hline
\end{tabular}


Table 2. Cont.

\begin{tabular}{|c|c|c|}
\hline $\begin{array}{l}\text { ATP synthase, } \mathrm{H}+\text { transporting, mitochondrial } \\
\text { F1 complex, } \alpha \text { subunit, isoform } 1\end{array}$ & $\begin{array}{l}\text { Mitochondria } \\
\text { Cytoplasm } \\
\text { Nucleus }\end{array}$ & $\begin{array}{l}\text { Produces ATP from ADP in the presence of a } \\
\text { proton gradient across the membrane. }\end{array}$ \\
\hline BBF2H7/FUS protein & Nucleus & $\begin{array}{l}\text { Binds both single-stranded and double-stranded } \\
\text { DNA and promotes ATP-independent annealing of } \\
\text { complementary single-stranded DNAs and d-loop } \\
\text { formation in superhelical double-stranded. }\end{array}$ \\
\hline Clusterin & $\begin{array}{l}\text { Cytoplasm } \\
\text { Nucleus }\end{array}$ & $\begin{array}{l}\text { Undefined function, being described as being both } \\
\text { pro-apoptotic and anti- apoptotic. }\end{array}$ \\
\hline $\begin{array}{l}\text { Cytidine monophospho-N-acetylneuraminic acid } \\
\text { synthetase }\end{array}$ & $\begin{array}{l}\text { Cytoplasm } \\
\text { Nucleus }\end{array}$ & $\begin{array}{l}\text { Involved in the biosynthesis of sialo-glycoproteins } \\
\text { and gangliosides. }\end{array}$ \\
\hline Desmoyokin/AHNAK & $\begin{array}{l}\text { Plasma } \\
\text { Membrane } \\
\text { Cytoplasm } \\
\text { Nucleus } \\
\end{array}$ & $\begin{array}{l}\text { Involved in the formation of cytoskeletal structure, } \\
\text { calcium homeostasis, and muscle regeneration. }\end{array}$ \\
\hline DNA ligase III $\alpha$ and $\beta$ & Nucleus & $\begin{array}{l}\text { Interacts with DNA-repair protein XRCC1 and } \\
\text { corrects defective DNA strand-break repair and } \\
\text { sister chromatid exchange. }\end{array}$ \\
\hline $\begin{array}{l}\text {-DnaK-type molecular chaperone hsp72-ps1 } \\
\text {-Heat shock } 27 \mathrm{kD} \text { protein } 1 \\
\text {-Heat shock cognate } 71 \mathrm{kDa} \text { protein (Heat shock } \\
70 \mathrm{kDa} \text { protein } 8 \text { ). }\end{array}$ & $\begin{array}{l}\text { Cytosol } \\
\text { Perinuclear } \\
\text { Mitochondria } \\
\text { Endoplasmatic } \\
\text { Reticulum } \\
\text { Nucleus } \\
\end{array}$ & $\begin{array}{l}\text { Chaperone activity, thermotolerance, inhibition of } \\
\text { apoptosis, regulation of cell development and cell } \\
\text { differentiation. }\end{array}$ \\
\hline DNA-repair protein complementing & Nucleus & Nucleotide excision repair (NER) of DNA. \\
\hline $\begin{array}{l}\text {-Far upstream element-binding protein } 1 \text { (FUSE- } \\
\text { binding protein 1) } \\
\text {-KH-type splicing regulatory protein (FUSE } \\
\text { binding protein 2) } \\
\text {-KSRP }\end{array}$ & $\begin{array}{l}\text { Nucleus } \\
\text { (Probable). }\end{array}$ & $\begin{array}{l}\text { Regulates MYC expression by binding to a far- } \\
\text { upstream element (FUSE) upstream of the MYC } \\
\text { promoter. }\end{array}$ \\
\hline $\begin{array}{l}\text { Grainyhead-like protein } 2 \text { homolog (Brother of } \\
\text { mammalian grainyhead) (Transcription factor } \\
\text { CP2-like 3) }\end{array}$ & Nucleus & $\begin{array}{l}\text { Transcription factor involved in epidermal } \\
\text { differentiation. }\end{array}$ \\
\hline $\begin{array}{l}\text { GTP-binding nuclear protein Ran, testis-specific } \\
\text { isoform }\end{array}$ & $\begin{array}{l}\text { Cytoplasm } \\
\text { Nucleus }\end{array}$ & $\begin{array}{l}\text { Nuclear transport pathways, required for the import } \\
\text { of protein into the nucleus and also for RNA export. }\end{array}$ \\
\hline Gyceraldehyde-3-phosphate dehydrogenase & $\begin{array}{l}\text { Membrane } \\
\text { Cytoplasm } \\
\text { Nucleus }\end{array}$ & $\begin{array}{l}\text { Carbohydrate metabolism and membrane trafficking } \\
\text { in the early secretory pathway. }\end{array}$ \\
\hline Methyl CpG binding protein 2 & Nucleus & $\begin{array}{l}\text { Nuclear proteins containing a methyl-binding } \\
\text { domain (MBD) }\end{array}$ \\
\hline M-phase phosphoprotein 4 & Nucleolus & $\begin{array}{l}\text { Regulation of cell cycle, cell communication and } \\
\text { signal transduction. }\end{array}$ \\
\hline
\end{tabular}


Table 2. Cont.

\begin{tabular}{|c|c|c|}
\hline Mucin & $\begin{array}{l}\text { Cytoplasm } \\
\text { Mitochondria } \\
\text { Nucleus }\end{array}$ & Activation of Wnt target genes. \\
\hline $\begin{array}{l}\text { Nucleoporin } 35 \text { [Nuclear pore glycoprotein-210 } \\
\text { (gp210)] }\end{array}$ & $\begin{array}{l}\text { Membrane } \\
\text { Cytoplasm } \\
\text { Nucleus }\end{array}$ & $\begin{array}{l}\text { Trafficking regulator in the eukaryotic nuclear pore } \\
\text { complex. }\end{array}$ \\
\hline p80 protein & $\begin{array}{l}\text { Cytoplasm } \\
\text { Nucleus }\end{array}$ & $\begin{array}{l}\text { Part of the nuclear coiled bodies (CBS) involved in } \\
\text { assembly/disassembly of nucleoplasmic snRNPs. }\end{array}$ \\
\hline Paraspeckle component 1 & $\begin{array}{l}\text { Cytoplasm } \\
\text { Nucleus } \\
\text { Nucleolus }\end{array}$ & $\begin{array}{l}\text { Regulates cooperatively with NONO and SFPQ, } \\
\text { androgen receptor-mediated gene transcription } \\
\text { activity. }\end{array}$ \\
\hline PREDICTED: similar to RAN protein & $\begin{array}{l}\text { Cytoplasm } \\
\text { Nucleus }\end{array}$ & Inhibits GTP exchange on Ran. \\
\hline Regulator of chromosome condensation ( $\mathrm{RCC} 1$ ) & $\begin{array}{l}\text { Cytoplasm } \\
\text { Nucleus }\end{array}$ & Promotes the exchange of Ran-bound GDP by GTP \\
\hline Retinoblastoma binding protein 7 & Nucleus & $\begin{array}{l}\text { Modulates the functions ascribed to BRCA1 in } \\
\text { transcriptional regulation, DNA repair, and/or cell } \\
\text { cycle checkpoint control. }\end{array}$ \\
\hline SERPINE1 mRNA binding protein 1 isoform 1 & $\begin{array}{l}\text { Cytoplasm } \\
\text { Nucleus }\end{array}$ & Regulates mRNA stability. \\
\hline SPIN & Nucleus & Regulation of cell cycle \\
\hline Sterile alpha motif domain containing 1 & Nucleus & $\begin{array}{l}\text { Widespread domain in signalling and nuclear } \\
\text { proteins. }\end{array}$ \\
\hline Thymopoietin $\gamma$ and $\beta$ ( TMPOs) & Nucleus & Directs the assembly of the nuclear lamina. \\
\hline Transcription factor A, mitochondrial & Mitochondria & Involved in mitochondrial transcription regulation. \\
\hline UV excision repair protein RAD23 homolog B & $\begin{array}{l}\text { Cytoplasm } \\
\text { Nucleus }\end{array}$ & $\begin{array}{l}\text { Plays a role both in proteosomal degradation of } \\
\text { misfolded proteins and DNA repair. }\end{array}$ \\
\hline
\end{tabular}

\subsection{Identification of IGF-IR Promoter-Binding Transcription Factors by Western Blots}

Western blot analysis of DNA affinity chromatography-purified proteins identified a number of previously reported as well as novel IGF-IR promoter binding proteins. The data are summarized in Figure 4 and Tables 3 and 4 . Consistent with their role as positive regulators of the IGF-IR gene, the binding of zinc finger proteins Sp1 and KLF6 to the IGF-IR promoter was stronger in MCF7 than in C4.12.5 cells. Similarly, ER- $\alpha$ binding to the IGF-IR promoter was stronger in MCF7 than in C4.12.5 cells. On the other hand, a number of transcription factors, including AR, Smad2/3, E2F1, cjun, TCF1A, TCF3A, GSK3 $\beta$, and p21 appear to bind to the promoter region only in the C4.12.5 cell line. p53, c-fos, and PARP bind to IGF-IR promoter elements in both cell lines with similar affinity. No DNA binding was detected in either cell line using antibodies against BRCA1, TOPOII, IRS-1, MET, p120, Foxo1, p73, lamin A/C, c-Myc, p63, cyclin D, cyclin G, histone1, and BRCA2. 
Figure 4. IGF-IR promoter-binding transcription factors identified by Western blots in the MCF7 and C4.12.5 cell lines. DNA chromatography eluates were electrophoresed though $10 \%$ SDS-PAGE and blotted with the antibodies listed under Materials and Methods Section. The left lanes correspond to nuclear extracts (NE; $4.2 \mu \mathrm{g})$ and the right lanes correspond to DNA affinity chromatography eluates (E; $10 \mu \mathrm{g})$.
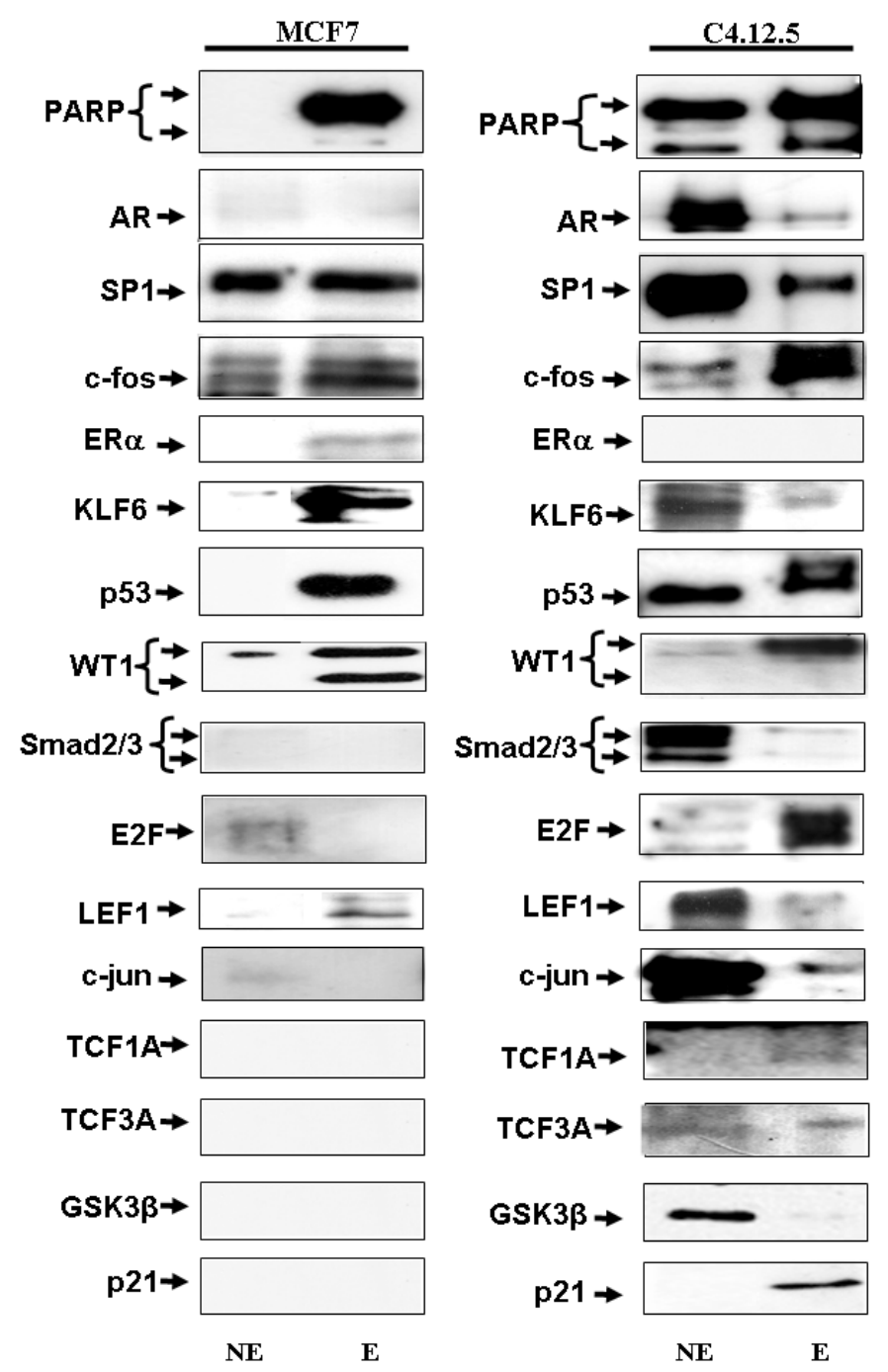

Table 3. Differentially expressed nuclear proteins identified by Westen blots in MCF7 and C4.12.5 cells.

\begin{tabular}{llll}
\hline Gene & MCF7 & C4.12.5 & \multicolumn{1}{c}{ Nomenclature } \\
\hline BRCA1 & 1 & 0.3 & Breast and ovarian cancer type I \\
TOPOII & 1 & 0 & Type II topoisomerase \\
IRS-I & 0 & 0 & Insulin receptor substrate-1 \\
PARP & 1 & 2 & Poly ADP ribose polymerase \\
MET & 1 & 0 & Met tyrosine kinase \\
p120 & 1 & 1.39 & Zinc finger protein 120 \\
AR & 1 & 0.64 & Androgen receptor \\
Sp1 & 1 & 0.79 & Trans-acting transcription factor 1 \\
Foxo1 & 1 & 0.5 & Forkhead Box A1 \\
\hline
\end{tabular}


Table 3. Cont.

\begin{tabular}{llll}
\hline ER & 1 & 0.59 & Estrogen receptor \\
WT1 & 1 & 0.8 & Wilms' tumor suppressor gene-1 \\
KLF6 & 1 & 1.2 & Kruppel-like factor 6 \\
LaminA/C & 1 & 2.4 & Nuclear protein \\
Smad 2 & 1 & 1.12 & \\
Smad 3 & 0 & 2.6 & Smad 2/3 family \\
pSmad2/3 & 1 & 1.13 & \\
c-Myc & 1 & 1.48 & Myelocytomatosis oncogene \\
E2F1 & 1 & 0.88 & E2F transcription factor 1 \\
TCF1 & 1 & 0.717 & T-cell factor 1 \\
TCF3A & 1 & 0.002 & High Mobility Group box transcription factor 3 \\
LEF1 & 1 & 1.15 & Lymphoid enhancer binding factor 1 \\
p53 & 1 & 0.96 & \\
p63 & 1 & 1.12 & p53-related tumor suppressors \\
p73 & 1 & 0.03 & \\
p21 & 1 & 0.91 & Waf1/Cip1 \\
GSK3 $\alpha$ & 1 & 1.05 & Glycogen Synthase Kinase-3 \\
c-fos & 1 & 0.92 & \\
c-jun & 1 & 10 & c-fos/c-jun family of transcription factors \\
pc-jun & 1 & 0.5 & \\
Cyclin G & 1 & 0.13 & Regulatory subunits of Cdc2 p34 \\
Cyclin D & 1 & 0 & Nuclear protein \\
Histone1 & 1 & 0.74 & level of expressin \\
\hline A value & 1 & was &
\end{tabular}

A value of 1 was assigned to the level of expression in whole MCF7 cell lysates, normalized to tubulin.

Table 4. Function of gene products identified in MCF7 and C4.12.5 cells by Western analyses.

\begin{tabular}{ll}
\hline Gene & \multicolumn{1}{c}{ Function } \\
\hline BRCA1 & $\begin{array}{l}\text { Tumor suppressor involved in DNA damage repair, cell growth and apoptosis, and } \\
\text { gene transcription. }\end{array}$ \\
TOPOII & $\begin{array}{l}\text { Type II topoisomerase, breaks double strands of duplex DNA. } \\
\text { IRIS-I }\end{array}$ \\
Mediates insulin related activities. \\
PARP & DNA repair, replication, transcription and cell death. \\
MET & Receptor for HGF/SF. \\
p120 & Prototypical member of a subfamily of armadillo (Arm)-domain proteins involved in \\
& intercellular adhesion and in nuclei. \\
AR & Androgen receptor (AR), a zinc finger transcription factor of the nuclear receptor \\
SP1 & superfamily. \\
Foxo1 & Transcription factor of the zinc finger family. \\
ER & Transcription factor of the forkhead family. \\
& Estrogen receptor (ER), a DNA binding transcription factor of the nuclear receptor \\
\end{tabular}


Table 4. Cont.

\begin{tabular}{ll}
\hline WT1 & Wilm's tumor suppressor protein-1. \\
KLF6 & Kruppel-like zinc finger transcription factor-6. \\
LaminA/C & Involved in nuclear stability, chromatin structure and gene expression. \\
pSmad 2/3 & Smad transcription factors mediate the effect of TGF- $\beta$. \\
Smad 2/3 & Nuclear proteins involved in cell proliferation, differentiation and neoplastic disease. \\
c-Myc & Involved in cell cycle progression, apoptosis and oncogenesis. \\
E2F1 & Members of the high mobility group (HMG) DNA binding protein family of \\
LEF1 & transcription factors. \\
TCFA1 & \\
TCF3A & \\
P53 & Tumor suppressor p53, p63 and p73. \\
p63 & \\
p73 & Involved in protein synthesis, cell adhesion, proliferation, and differentiation. \\
GSK3 $\alpha$ & \\
c-fos & \\
c-jun & Fos and Jun protooncogenes. \\
pc-jun & \\
Cyclin G & \\
Cyclin D & Regulatory subunits of Cdc2 p34 and related cyclin-dependent kinases (Cdks). \\
Histone1 & Basic and water soluble nuclear proteins. \\
p21 & Tumor suppressor protein p21/Waf1/Cip1 acts as an inhibitor of cell cycle progression. \\
\hline
\end{tabular}

\subsection{Cellular Distribution of IGF-IR Promoter-Binding Proteins}

Given that differences in binding could be due to differential expression of the transcription factors in both cell lines, we next investigated the subcellular distribution and expression of IGF-IR promoterbinding transcription factors. For this purpose, MCF7 and C4.12.5 lysates were fractionated into cytoplasmic and nuclear fractions and the subcellular distribution of the different proteins was examined by Western blots (Figure 5 and Tables 3 and 4). The cytosolic marker MET [47] was used to check for cytoplasmic contamination of the nuclear fraction, and it was found to be expressed at very low levels in both cell lines. A number of proteins, including PARP (200\% of levels in MCF7 cells), lamin (240\%), Smad 2/3 (260\%), and c-jun (1000\%) had higher expression levels in C4.12.5 than in MCF7 cells. Other proteins, such as BRCA1 (30\% of levels in MCF7), AR (64\%), Sp1 (79\%), Foxo I (50\%), p73 (3\%), TCF3A (0.2\%), ER (59\%), TCF1 (71.7\%), pc-jun (50\%), cyclin G (13\%), and histone (74\%) were expressed at lower levels in C4.12.5 compared to MCF7 cells. No differences in expression between the cell lines were detected in p120, c-fos, WT1, KLF6, pSmad2/3, c-Myc, p63, E2F, LEF1, p53, GSK3 $\alpha$, and p21. We were unable to detect expression of $\beta$-catenin, p300, TLE1, APC, and BRCA2 in neither cell line. Transcription factor WT1 was present in both cell lines, though its low molecular weight form appears to be specific to the MCF7 cell line. 
Figure 5. Cellular distribution of transcription factors in the MCF7 and C4.12.5 cell lines. Cell lines were fractionated as described under Materials and Methods and total lysates (T; $80 \mu \mathrm{g})$, cytosolic fractions ( ; $20 \mu \mathrm{g})$, and nuclear extracts $(\mathrm{N} ; 20 \mu \mathrm{g})$ were resolved on $10 \%$ SDS-PAGE and blotted with the indicated antibodies.

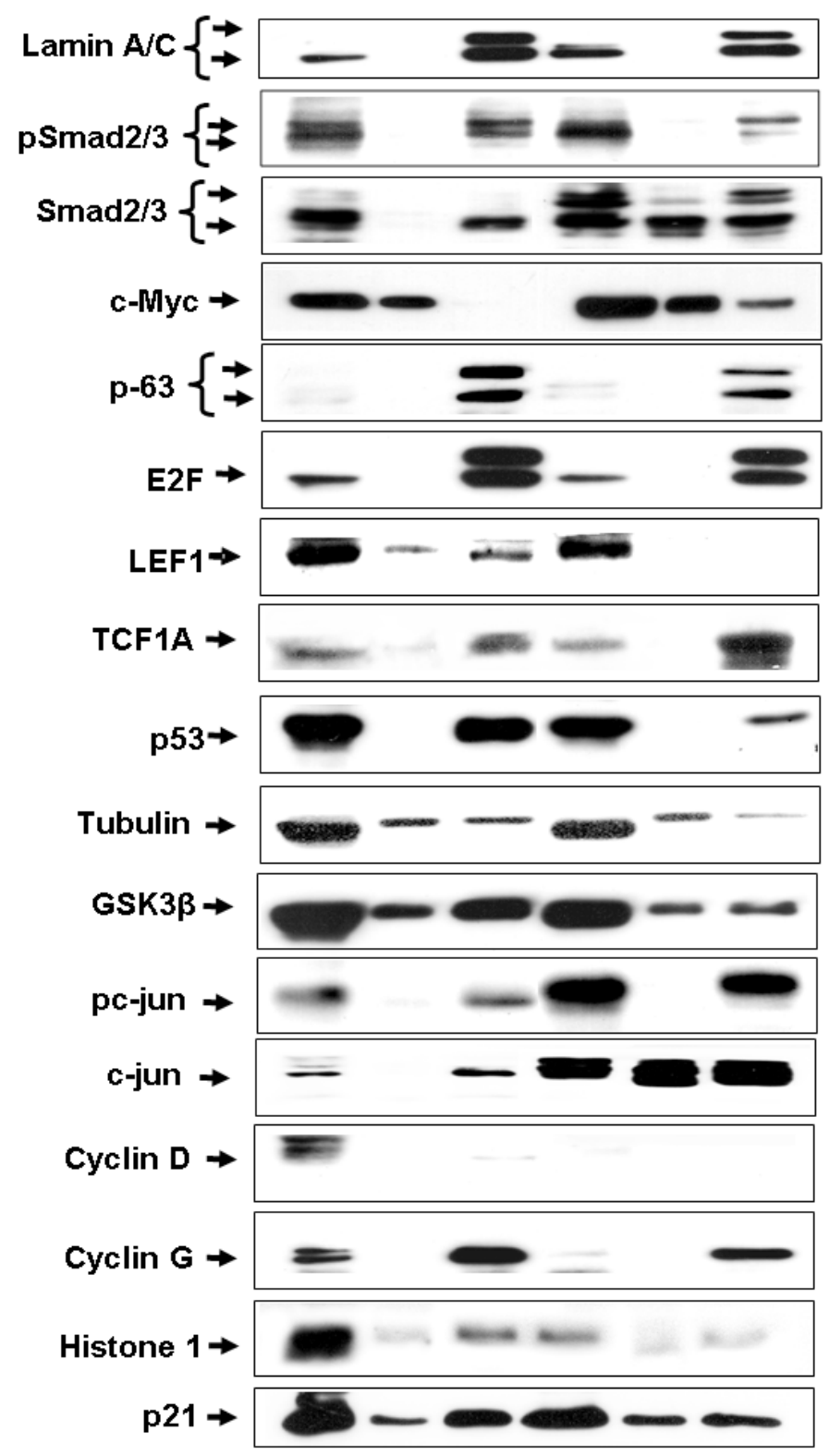

\subsection{ChIP Assays}

To corroborate results of DNA chromatography we measured the binding of selected proteins identified by MS or by Western blots using ChIP assays. The following proteins were chosen for ChIP assays: PARP (detected by MS and Western blots in both cell lines), Sp1 (positive control, detected in both cell lines), c-jun, (detected only in C4.12.5) and HMGA1 (detected by MS only in MCF7). Briefly, cells were lysed, sonicated for $3 \mathrm{~min}$, and immunoprecipitated with the indicated antibodies (or normal mouse or rabbit sera) for $18 \mathrm{~h}$ (Figure 6A). In addition, MCF7 cells transfected with HAHMGA1 (or empty pCDNA3 vector) were also immunoprecipitated with an HA monoclonal antibody (Figure 6B). For PCR analysis of immunoprecipitatd chromatin, a set of primers encompassing the 
human IGF-IR promoter was employed as described under Materials and Methods section. The input bands represent the amplified PCR product in the absence of antibodies (Figures 6A and 6B). The results of ChIP analyses confirmed that PARP, c-jun, Sp1, KLF6 and HMGA1 bound in vivo directly to the IGF-IR promoter and, thus, corroborate the results of MS and Western blot analyses.

Figure 6. ChIP assays of transcription factor binding to IGF-IR promoter DNA. (A). MCF7 cells were cross-linked with formaldehyde, lysed, sonicated, and immunoprecipitated with PARP, c-jun, Sp1, or KLF6 antibodies, or normal mouse or rabbit sera, followed by PCR amplification of precipitated chromatin using primers encompassing the IGF-IR promoter. The position of the $773 \mathrm{bp}$-amplified fragments is indicated. The input bands represent the amplified PCR product in the absence of antibodies. The insets indicate the endogenous levels of expression of the various proteins as measured by Western blots (WB) with specific antibodies or NRS or NMS as negative controls. IP, immunoprecipitation. (B). MCF7 cells were transfected with an expression vector encoding HA-HMGA1 (or empty pcDNA3 vector), after which the cells were cross linked with formaldehyde, lysed, sonicated and immunoprecipitated with an HA antibody, followed by PCR amplification of IGF-IR promoter DNA. HA-HMGA1 immunoprecipitated protein was detected by Western blots using an anti-HA antibody (inset).

(A)
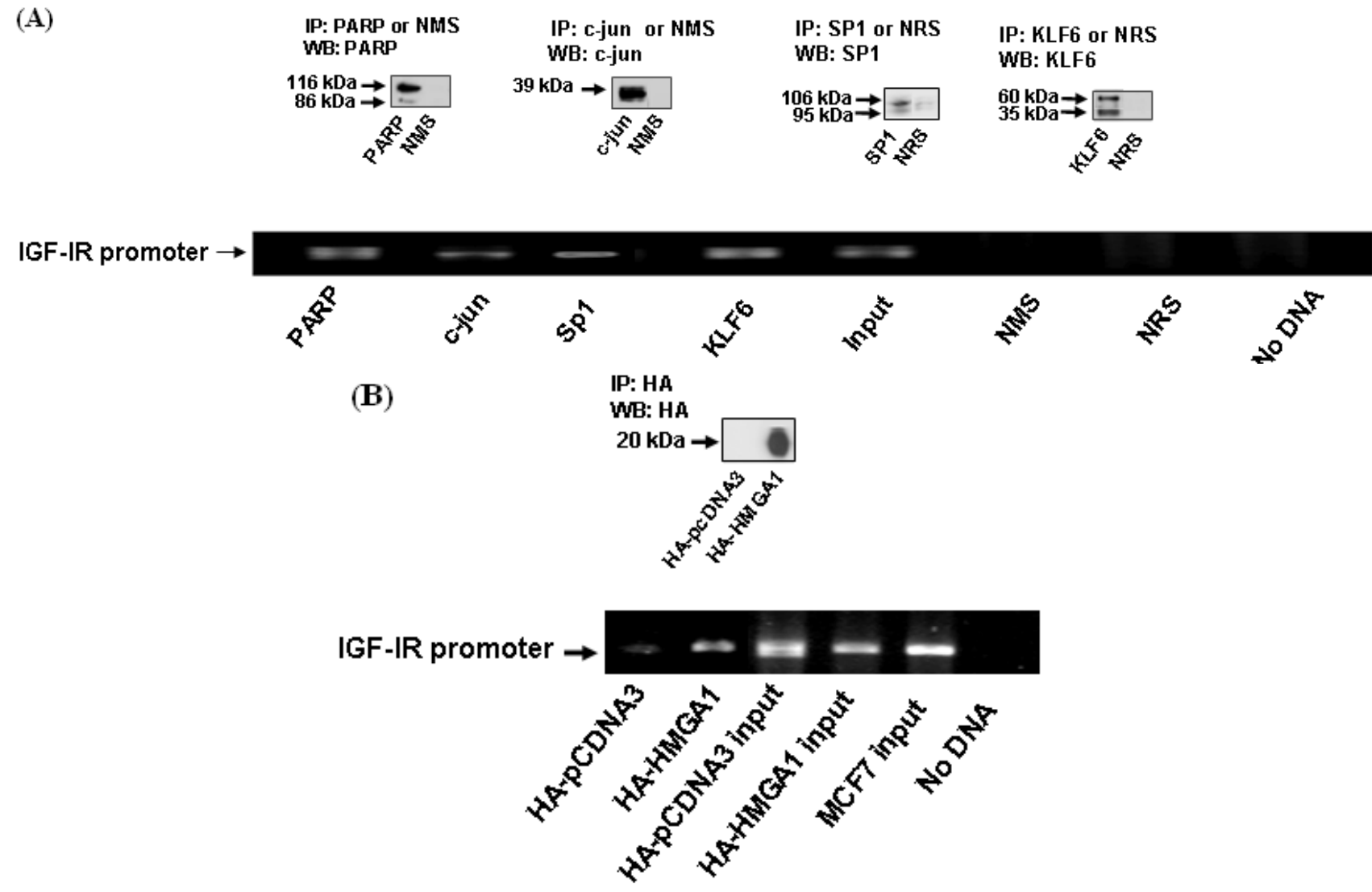

\subsection{Regulation of IGF-IR Promoter Activity by c-jun, HMGA1, KLF6 and E2F1}

To evaluate the potential functional implications of our findings we next assessed the ability of selected IGF-IR promoter-binding proteins to activate the promoter. For this purpose cotransfection 
experiments were performed in MCF7 and C4.12.5 cells using expression vectors encoding c-jun, HMGA1, KLF6 and E2F1, along with an IGF-IR promoter-luciferase reporter plasmid, $p(-476 /+640) L U C$, which contains most of the proximal region of the IGF-IR promoter. The results of cotransfection experiments are presented in Figures 7A-D. Results obtained indicate that transcription factors c-jun, KLF6, and E2F1 induced a significant increase in IGF-IR promoter activity in both cells lines. Specifically, c-jun enhanced IGF-IR promoter activity by $445 \pm 12.4 \%$ in MCF7 and by $209 \pm 3.1 \%$ in C4.12.5 cells (versus empty vector), KLF6 enhanced promoter acitiviy by $237 \pm 9.7 \%$ in MCF7 and by $159 \pm 7.1 \%$ in C4.12.5 cells, and E2F1 stimulated promoter activity by $631.5 \pm 44.5 \%$ in MCF7 and by $1127 \pm 22.2 \%$ in C4.12.5 cells. On the other hand, HMGA1 had a minimal effect $(131 \pm 4.3 \%$ increase in MCF7 and $80.3 \pm 1.7 \%$ reduction in C4.12.5 cells).

Figure 7. Regulation of IGF-IR promoter activity by c-jun, HMGA1, KLF6 or E2F1. MCF7 and C4.12.5 cells were cotransfected with the $\mathrm{p}(-476 /+640)$ LUC reporter construct along with c-jun (A), HMGA1 (B), KLF6 (C) or E2F1(D) expression plasmids (or empty expression vectors). Forty eight hours after transfection the cells were harvested and luciferase activity was measured. Promoter activities are expressed as luciferase values normalized to protein concentration. A value of $100 \%$ was given to the promoter activity generated by the reporter plasmid in empty vector-transfected MCF-7 or C4.12.5 cells. The results represent the mean \pm SEM $(\mathrm{N}=3$ independent experiments in triplicate wells); $* p<0.01$ versus empty vector-tranfected cells and $* * p<0.01$ versus specific vectortransfected MCF7 cells.

(A)

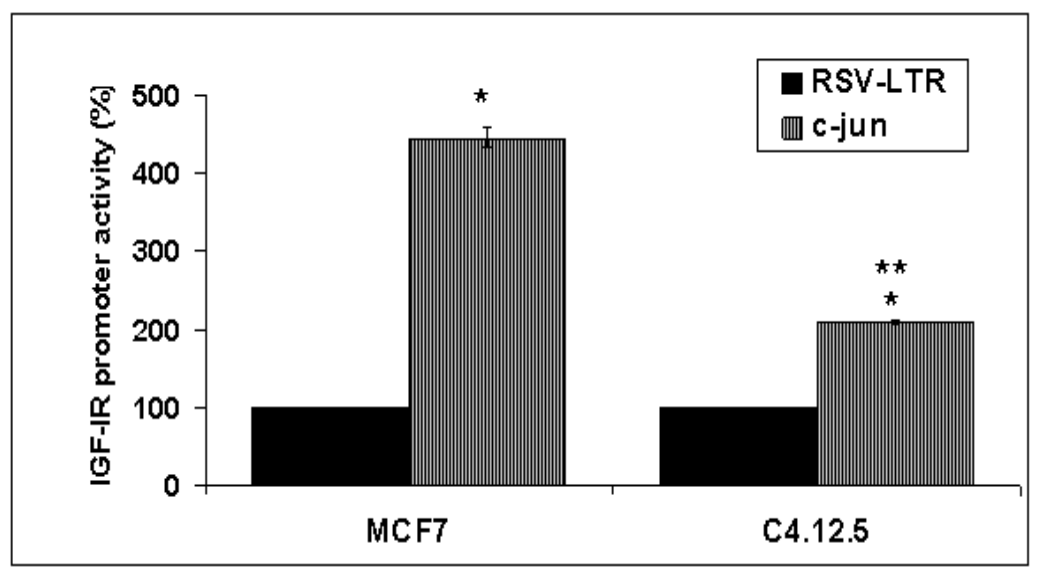

(B)

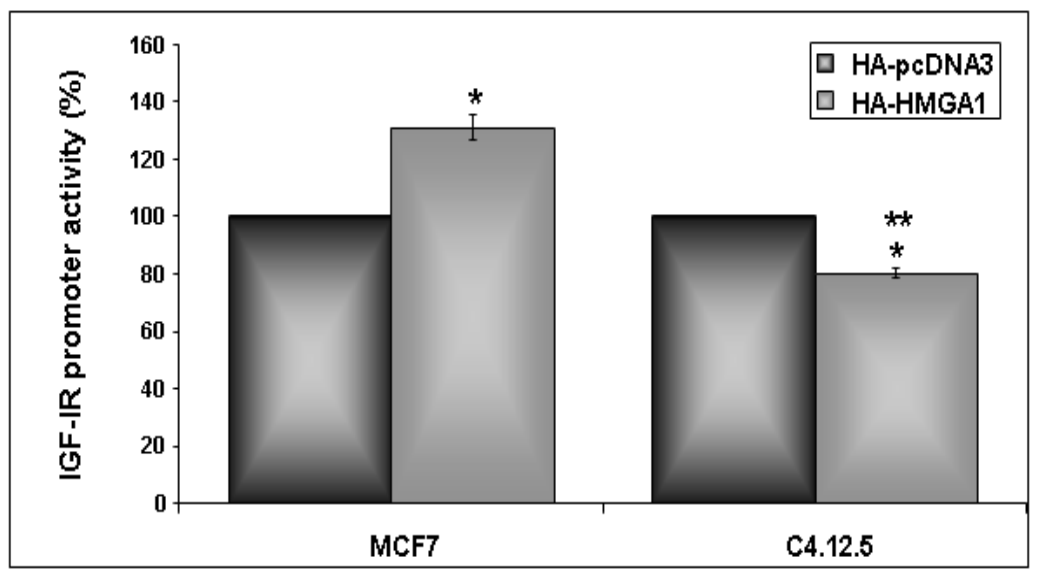


Figure 7. Cont.

(C)

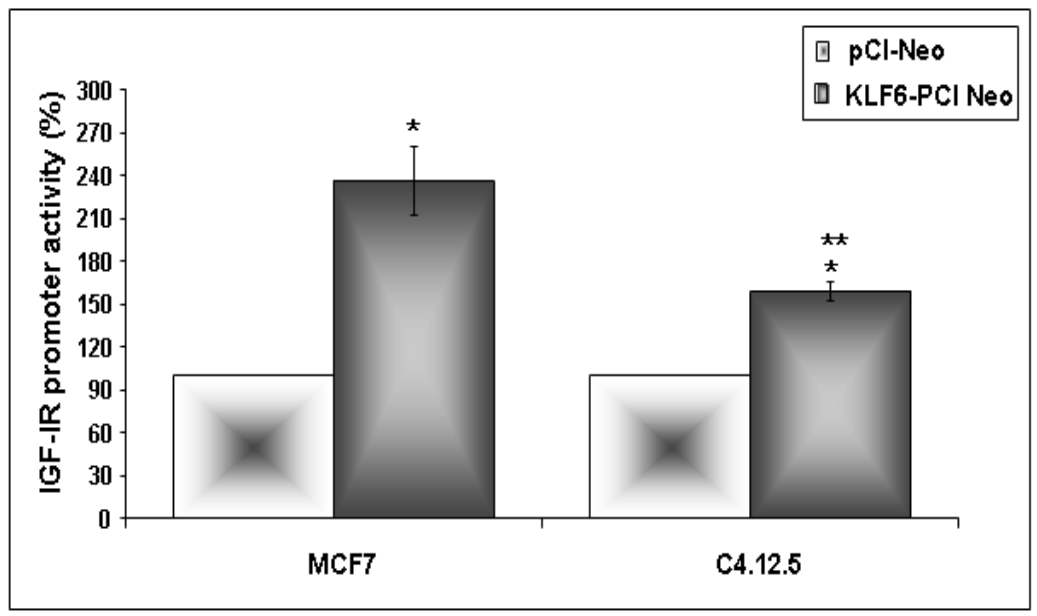

(D)

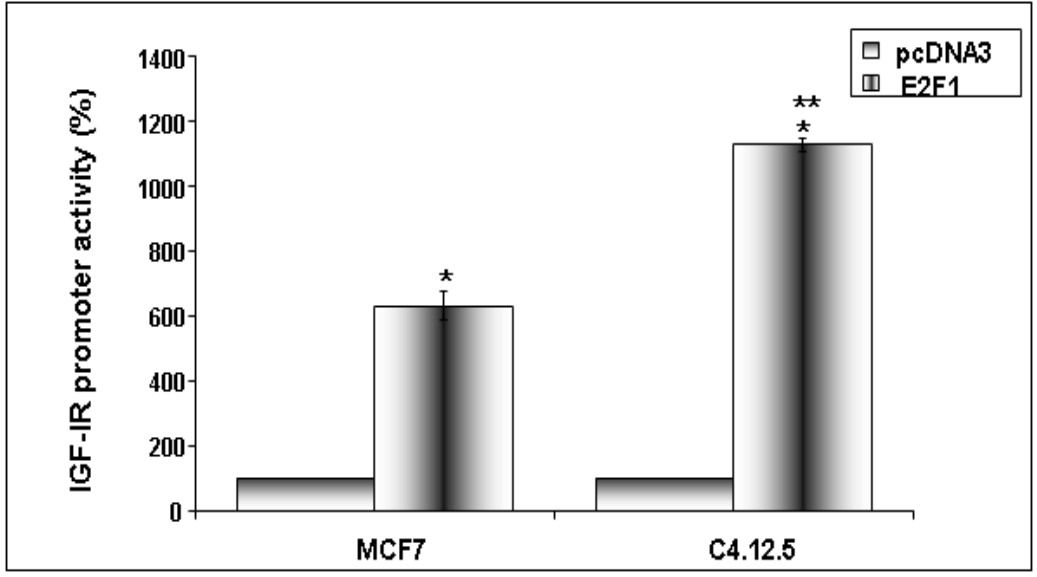

\section{Discussion}

Breast cancer is one of the main causes of cancer-related mortality among women in economically developed regions of the world. Care of patients with breast cancer is complicated by the wide differences in the natural history of the disease, as manifested by a remarkable variability in response to treatment and survival. Over 100 potential biomarkers were reported in various studies to be differentially expressed between normal and cancerous cells and tissues. Cancer biomarkers include, among others, ER, progesterone receptor, HER2, cathepsin D, cyclin E, CA 15-3, and CA 27.29. Currently, only a few of those biomarkers are used in clinical practice. High-throughput genomic and proteomic techniques developed over the last decade offer the potential to better define the biological nature of the disease process, both for risk assessment and therapy purposes [48].

There is conflicting evidence regarding the importance of IGF-IR expression for diagnosis and prognosis of breast cancer. In different studies, IGF-IR expression was detected in $39 \%$ to $93 \%$ of the cases [49]. Whereas some studies reported that IGF-IR levels are indicative of early recurrence of the disease (i.e., poor prognosis), others considered high IGF-IR values as an indication of good prognosis [4,50-54]. These disparities may be due to a number of factors, including selection of patients or the diverse approaches used to detect IGF-IR, including immunoblots of membrane fractions and/or whole tissues, ligand binding assays, etc. Immunohistochemical studies revealed high IGF-IR and IRS-1 levels in control breast tissues and in well-differentiated breast carcinoma, whereas 
very low levels were seen in poorly differentiated cancers [3]. These results, suggesting that progression to advanced-stage disease is associated with a reduction in IGF-IR expression, indicate that IGF-IR status can be used as a marker for tumor evaluation [3]. Notably, no correlation was seen between insulin receptor levels and the differentiation stage of the tumors.

In the present study we employed a novel and reliable DNA affinity chromatography protocol in order to identify IGF-IR promoter-binding proteins in breast cancer cells. This method allowed us to detect known and new specific potential biomarkers in ER-positive and ER-depleted cells, which may reflect early and advanced stages of the disease. Our analyses identified twenty four proteins that bind to the IGF-IR promoter only in MCF7 cells whereas, on the other hand, C4.12.5 cells contain nineteen proteins that did not exhibit IGF-IR promoter binding activity in MCF7 cells. The results obtained suggest that the specific binding of different DNA-binding transcription factors and non-DNA sequence specific-binding nuclear proteins (including Smad2/3, LEF1, c-jun, TCF1A, TCF3A, GSK3 $\beta$ and others ) in the MCF7 and C4.12.5 cell lines could reflect differences in transcriptional regulation of the IGF-IR gene at different stages of the disease. Interestingly, sixty two proteins were shown to bind (either directly or indirectly) to IGF-IR promoter elements in both cell lines. As shown in Tables 2 and 4, the list of proteins identified in this study includes proteins involved in apoptosis, protein synthesis, cell adhesion, proliferation, differentiation, nuclear stability, chromatin structure, DNA repair, recombination, replication, tumor suppression, and oncogenesis. In this context, it has been previously shown that the regulatory region of the IGF-IR gene constitutes a molecular target for a number of transcription factors with tumor suppressor or stimulatory activity [46]. Under normal physiological conditions, IGF-IR expression is tightly regulated by complex interactions involving positively acting (Sp1, KLF-6, ER $\alpha$ ) and negatively acting (p53, p73, BRCA1, ATM, WT1, VHL) transcription factors [17,18,22-24,40,45,55-57]. Elevated IGF-IR levels were postulated to be the result of loss-of-function mutations of tumor suppressor genes in cancer cells [58]. The approach employed in this study allowed us to identify several previously reported IGF-IR promoter-binding proteins, including Sp1, KLF6, and WT1. Moreover, results of MS and Western blots confirmed bioinformatic predictions on transcription factor binding sites (e.g., WT1, ER, E2F, Sp1, etc.), obtained using the TRANSFAC and AliBaba2 softwares (http://www.biobase-international.com and http://www.gene-regulation.com) (data not shown). Furthermore, the fact that we were able to detect differences in promoter binding between the two cell lines, despite the lack of differences in protein expression, indicates that the DNA affinity chromatography approach used was highly specific and sensitive. Given that differences in binding could be due to differences in the availability of these proteins, we confirmed that the proteins detected in the eluates were truly present in the nuclear fractions. Several proteins, including KLF6, Smad2/3, GSK3 $\beta$, c-jun, and p21, were present in both cytosolic and nuclear fractions. A number of transcription factors, including BRCA1, p120, Foxo1, p73, c-myc, p63, cyclin D and G, were undetectable in eluates of both cell lines. A potential explanation for these results is the fact that the expression of these transcription factors was very low in the nuclear fractions [59] or, alternatively, that they are engaged in multi-protein complexes and, therefore, cannot bind to IGF-IR promoter sequences.

The capacity of a number of proteins identified by MS and/or Western blots (PARP, Sp1, c-jun, HMGA1) to directly bind to IGF-IR promoter DNA in vivo was confirmed by ChIP assays. Furthermore, the functional relevance of binding data was addressed by coexpression experiments 
which revealed that c-jun, KLF6, and E2F1 significantly enhanced IGF-IR promoter activity. Differences in the capacity of these factors to stimulate IGF-IR promoter activity was seen between both cell lines. The luciferase assays corroborate the results obtained by Western blots and ChIP assays. We have previously shown using EMSA and ChIP that both Sp1 and ER $\alpha$ bind to the IGF-IR promoter and stimulate gene transcription, whereas no ER $\alpha$ binding was seen in C4 cells [60]. In addition, we have reported that $\mathrm{Sp} 1$ increased IGF-IR promoter activity with a 5.8-fold higher potency in MC7 than in C4 cells [60]. Taken together, there is a remarkable consistency between the various technological approaches used to identify IGF-IR promoter-binding transcription factors.

\section{Conclusions}

In summary, using DNA affinity chromatography we identified a collection of known and novel IGF-IR promoter-binding transcription factors in breast cancer cell lines. These proteins may constitute potential biomarkers characteristic of ER-positive or ER-negative tumors. The potential clinical relevance of our results need to be confirmed by future studies on biopsies from patients at early and advanced stages, and need to be correlated with conventional prognostic factors such as tumor size, lymph nodes status, histological grade, and ER status.

\section{Acknowledgements}

The authors wish to thank W.V. Welshons, S.L. Friedman, L. Vardimon, H. Eldar-Finkelman, and G. Manfioletti for providing cell lines and reagents, and the Smoler Proteomics Center at the Technion, Haifa, Israel for the MS analyses. This work was supported by the Cooperation Program in Cancer Research of the Deutsches Krebsforschungszentrum (DKFZ) and Israel's Ministry of Science and Technology (MOST). A.B. wishes to thank the Associazione Italiana per la Ricarca sul Cancro for grant support.

\section{References}

1. Werner, H.; LeRoith, D. The role of the insulin-like growth factor system in human cancer. Adv. Cancer Res. 1996, 68, 183-223.

2. Yee, D.; Paik, S.; Lebovic, G.S.; Marcus, R.R.; Favoni, R.E.; Cullen, K.J.; Lippman, M.E.; Rosen, N. Analysis of insulin-like growth factor I gene expression in malignancy: evidence for a paracrine role in human breast cancer. Mol. Endocrinol. 1989, 3, 509-517.

3. Schnarr, B.; Strunz, K.; Ohsam, J.; Benner, A.; Wacker, J.; Mayer, D. Down-regulation of insulinlike growth factor-I receptor and insulin receptor substrate-1 expression in advanced human breast cancer. Int. J. Cancer 2000, 89, 506-513.

4. Surmacz, E. Function of the IGF-I receptor in breast cancer. J. Mammary Gland Biol. Neoplasia 2000, 5, 95-105.

5. LeRoith, D.; Werner, H.; Beitner-Johnson, D.; Roberts, C.T., Jr. Molecular and cellular aspects of the insulin-like growth factor I receptor. Endocr. Rev. 1995, 16, 143-163. 
6. Sell, C.; Rubini, M.; Rubin, R.; Liu, J.-P.; Efstratiadis, A.; Baserga, R. Simian virus 40 large tumor antigen is unable to transform mouse embryonic fibroblasts lacking type 1 insulin-like growth factor receptor. Proc. Natl. Acad. Sci. USA 1993, 90, 11217-11221.

7. Sell, C.; Dumenil, G.; Deveaud, C.; Miura, M.; Coppola, D.; DeAngelis, T.; Rubin, R.; Efstratiadis, A.; Baserga, R. Effect of a null mutation of the insulin-like growth factor I receptor gene on growth and transformation of mouse embryo fibroblasts. Mol. Cell. Biol. 1994, 14, 3604-3612.

8. Arteaga, C.L.; Kitten, L.J.; Coronado, E.B.; Jacobs, S.; Kull, F.C., Jr.; Allred, D.C.; Osborne, C.K. Blockade of the type I somatomedin receptor inhibits growth of human breast cancer cells in athymic mice. J. Clin. Invest. 1989, 84, 1418-1423.

9. Surmacz, E.; Guvakova, M.; Nolan, M.; Nicosia, R.; Sciacca, L. Type I insulin-like growth factor receptor function in breast cancer. Breast Cancer Res. Treat. 1998, 47, 255-267.

10. Van der Burg, B.; Isbrucker, L.; Van Selm-Miltenburg, A.J.; de Laat, S.W.; Van Zoelen, E.J. Role of estrogen-induced insulin-like growth factors in the proliferation of human breast cancer cells. Cancer Res. 1990, 50, 7770-7774.

11. Cullen, K.I.; Yee, D.; Sly, W.S.; Perdue, J.; Hampton, B.; Lippman, M.E.; Rosen, N. Insulin-like growth factor receptor expression and function in human breast cancer. Cancer Res. 1990, 50, 48-53.

12. Wu, J.D.; Odman, A.; Higgins, L.M.; Haugk, K.; Vessella, R.; Ludwig, D.L.; Plymate, S.R. In vivo effects of the human type I insulin-like growth factor receptor antibody A12 on androgendependent and androgen-independent xenograft human prostate tumors. Clin. Cancer Res. 2005, $11,3065-3074$.

13. Ji, Q.S.; Mulvihill, M.J.; Rosenfeld-Franklin, M.; Cooke, A.; Feng, L.; Mak, G.; O'Connor, M.; Yao, Y.; Pirritt, C.; Buck, E.; Eyzaguirre, A.; Arnold, L.D.; Gibson, N.W.; Pachter, J.A. A novel, potent, and selective insulin-like growth factor-I receptor kinase inhibitor blocks insulin-like growth factor-I receptor signaling in vitro and inhibits insulin-like growth factor-I receptor dependent tumor growth in vivo. Mol. Cancer Ther. 2007, 6, 2158-2167.

14. Liu, W.; Bloom, D.A.; Cance, W.G.; Kurenova, E.V.; Golubovskaya, V.M.; Hochwald, S.N. FAK and IGF-IR interact to provide survival signals in human pancreatic adenocarcinoma cells. Carcinogenesis 2008, 29, 1096-1107.

15. Hankinson, S.E.; Willett, W.C.; Colditz, G.A.; Hunter, D.J.; Michaud, D.S.; Deroo, B.; Rosner, B.; Speizer, F.E.; Pollak, M. Circulating concentrations of insulin-like growth factor-I and risk of breast cancer. Lancet 1998, 351, 1393-1396.

16. Renehan, A.G.; Zwahlen, M.; C, M.; O'Dwyer, S.T.; Shalet, S.M.; Egger, M. Insulin-like growth factor-I, IGF binding protein-3, and cancer risk: systematic review and meta-regression analysis. Lancet 2004, 363, 1346-1353.

17. Beitner-Johnson, D.; Werner, H.; Roberts, C.T., Jr; LeRoith, D. Regulation of insulin-like growth factor I receptor gene expression by Sp1: Physical and functional interactions of Sp1 at GC boxes and at a CT element. Mol. Endocrinol. 1995, 9, 1147-1156.

18. Rubinstein, M.; Idelman, G.; Plymate, S.R.; Narla, G.; Friedman, S.L.; Werner, H. Transcriptional activation of the IGF-I receptor gene by the Kruppel-like factor-6 (KLF6) tumor suppressor protein: potential interactions between KLF6 and p53. Endocrinology 2004, 145, 3769-3777.

19. Abramovitch, S.; Glaser, T.; Ouchi, T.; Werner, H. BRCA1-Sp1 interactions in transcriptional regulation of the IGF-IR gene. FEBS Lett. 2003, 541, 149-154. 
20. Idelman, G.; Glaser, T.; Roberts, C.T., Jr; Werner, H. WT1-p53 interactions in IGF-I receptor gene regulation. J. Biol. Chem. 2003, 278, 3474-3482.

21. Werner, H.; Karnieli, E.; Rauscher, F.J., III; LeRoith, D. Wild type and mutant p53 differentially regulate transcription of the insulin-like growth factor I receptor gene. Proc. Natl. Acad. Sci. USA 1996, 93, 8318-8323.

22. Werner, H.; Re, G.G.; Drummond, I.A.; Sukhatme, V.P.; Rauscher, F.J., III; Sens, D.A.; Garvin, A.J.; LeRoith, D.; Roberts, C.T., Jr. Increased expression of the insulin-like growth factor-I receptor gene, IGFIR, in Wilms' tumor is correlated with modulation of IGFIR promoter activity by the WT1 Wilms' tumor gene product. Proc. Natl. Acad. Sci. USA 1993, 90, 5828-5832.

23. Yuen, J.S.P.; Cockman, M.E.; Sullivan, M.; Protheroe, A.; Turner, G.D.H.; Roberts, I.S.; Pugh, C.W.; Werner, H.; Macaulay, V.M. The VHL tumor suppressor inhibits expression of the IGF1R and its loss induces IGF1R upregulation in human clear cell renal carcinoma. Oncogene 2007, 26, 6499-6508.

24. Nahor, I.; Abramovitch, S.; Engeland, K.; Werner, H. The p53-family members p63 and p73 inhibit insulin-like growth factor-I receptor gene expression in colon cancer cells. Growth Hormone IGF Res. 2005, 15, 388-396.

25. Lee, A.V.; Jackson, J.G.; Gooch, J.L.; Hilsenbeck, S.G.; Coronado-Heinsohn, E.; Osborne, C.K.; Yee, D. Enhancement of insulin-like growth factor signaling in human breast cancer: estrogen regulation of insulin receptor substrate-1 expression in vitro and in vivo. Mol. Endocrinol. 1999, 13, 787-796.

26. Umayahara, Y.; Kawamori, R.; Watada, H.; Imano, E.; Iwama, N.; Morishima, T.; Yamasaki, Y.; Kajimoto, Y.; Kamada, T. Estrogen regulation of the insulin-like growth factor I gene transcription involves an AP-1 enhancer. J. Biol. Chem. 1994, 269, 16433-16442.

27. Osborne, C.K.; Coronado, E.B.; Kitten, L.J.; Arteaga, C.I.; Fuqua, S.A.W.; Ramasharma, K.; Marshall, M.; Li, C.H. Insulin-like growth factor-II (IGF-II): a potential autocrine/paracrine growth factor for human breast cancer acting via the IGF-I receptor. Mol. Endocrinol. 1989, 3, 1701-1709.

28. Stewart, A.J.; Johnson, M.D.; May, F.E.B.; Westley, B.R. Role of insulin-like growth factors and the type I insulin-like growth factor receptor in the estrogen stimulated proliferation of human breast cancer cells. J. Biol. Chem. 1990, 265, 21172-21178.

29. Salerno, M.; Sisci, D.; Mauro, L.; Guvakova, M.A.; Ando, S.; Surmacz, E. Insulin receptor substrate 1 is a target for the pure antiestrogen ICI 182,780 in breast cancer cells. Int. J. Cancer 1999, 81, 299-304.

30. McGuire, W.; Jackson, J.G.; Figueroa, J.A.; Shimasaki, S.A.; Powell, D.R.; Yee, D. Regulation of IGFBP expression by breast cancer cells: use of IGFBP-1 as an inhibitor of insulin-like growth factor action. J. Natl. Cancer Inst. 1992, 84, 1336-1341.

31. Mathieu, M.; Vignon, F.; Capony, F.; Rochefort, H. Estradiol down-regulates the mannose-6phosphate/insulin-like growth factor-II receptor gene and induces cathepsin-D in breast cancer cells: a receptor saturation mechanism to increase the secretion of lysosomal proenzymes. Mol. Endocrinol. 1991, 5, 815-822.

32. Kahlert, S.; Nuedling, S.; van Eickels, M.; Vetter, H.; Meyer, R.; Grohe, C. Estrogen receptor $\alpha$ rapidly activates the IGF-I receptor pathway. J. Biol. Chem. 2000, 275, 18447-18453. 
33. Kato, S.; Endoh, H.; Masuhiro, Y.; Kitamoto, T.; Uchiyama, S.; Sasaki, H.; Masushige, S.; Gotoh, Y.; Nishida, E.; Kawashima, H.; Metzger, D.; Chambon, P. Activation of the estrogen receptor through phosphorylation by mitogen-activated protein kinase. Science 1995, 270, 1491-1494.

34. Martin, M.B.; Franke, T.F.; Stoica, G.E.; Chambon, P.; Katzenellenbogen, B.S.; Stoica, B.A.; McLemore, M.S.; Olivo, S.E.; Stoica, A. A role for Akt in mediating the estrogenic functions of epidermal growth factor and insulin-like growth factor I. Endocrinology 2000, 141, 4503-4511.

35. Feng, W.; Webb, P.; Nguyen, P.; Liu, X.; Li, J.; Karin, M.; Kushner, P.J. Potentiation of estrogen receptor activation function 1 (AF-1) by Src/JNK through a serine 118-independent pathway. Mol. Endocrinol. 2001, 15, 32-45.

36. Joel, P.B.; Smith, J.; Sturgill, T.W.; Fisher, T.L.; Blenis, J.; Lannigan, D.A. pp90rsk1 regulates estrogen receptor-mediated transcription through phosphorylation of Ser-167. Mol. Cell Biol. 1998, 18, 1978-1984.

37. Oesterreich, S.; Zhang, P.; Guler, R.L.; Sun, X.; Curran, E.M.; Welshons, W.V.; Osborne, C.K.; Lee, A.V. Re-expression of estrogen receptor $\alpha$ in estrogen receptor $\alpha$-negative MCF-7 cells restores both estrogen and insulin-like growth factor-mediated signaling and growth. Cancer Res. 2001, 61, 5771-5777.

38. Cooke, D.W.; Bankert, L.A.; Roberts, C.T., Jr; LeRoith, D.; Casella, S.J. Analysis of the human type I insulin-like growth factor receptor promoter region. Biochem. Biophys. Res. Comm. 1991, 177, 1113-1120.

39. Beer, I.; Barnea, E.; Ziv, T.; Admon, A. Improving large-scale proteomics by clustering of mass spectrometry data. Proteomics 2004, 4, 950-960.

40. Maor, S.; Mayer, D.; Yarden, R.I.; Lee, A.V.; Sarfstein, R.; Werner, H.; Papa, M.Z. Estrogen receptor regulates insulin-like growth factor-I receptor gene expression in breast tumor cells: involvement of transcription factor Sp1. J. Endocrinol. 2006, 191, 605-612.

41. Werner, H.; Bach, M.A.; Stannard, B.; Roberts, C.T., Jr; LeRoith, D. Structural and functional analysis of the insulin-like growth factor I receptor gene promoter. Mol. Endocrinol. 1992, 6, $1545-1558$.

42. Werner, H.; Rauscher, F.J., III; Sukhatme, V.P.; Drummond, I.A.; Roberts, C.T., Jr; LeRoith, D. Transcriptional repression of the insulin-like growth factor I receptor (IGF-I-R) gene by the tumor suppressor WT1 involves binding to sequences both upstream and downstream of the IGF-I-R gene transcription start site. J. Biol. Chem. 1994, 269, 12577-12582.

43. Sgarra, R.; Lee, J.; Tessari, M.A.; Altamura, S.; Spolaore, B.; Giancotti, V.; Bedford, M.T.; Manfioletti, G. The AT-hook of the chromatin architectural transcription factor high mobility group A1a is arginine-methylated by protein arginine methyltransferase 6. J. Biol. Chem. 2006, 281, 3764-3772.

44. Berkovich, E.; Ginsberg, D. ATM is a target for positive regulation by E2F1. Oncogene 2003, 22, 161-167.

45. Reizner, N.; Maor, S.; Sarfstein, R.; Abramovitch, S.; Welshons, W.V.; Curran, E.; Lee, A.V.; Werner, H. The WT1 Wilms' tumor suppressor gene product interacts with estrogen receptoralpha and regulates IGF-I receptor gene transcription in breast cancer cells. J. Mol. Endocrinol. 2005, 35, 135-144. 
46. Sarfstein, R.; Maor, S.; Reizner, N.; Abramovitch, S.; Werner, H. Transcriptional regulation of the insulin-like growth factor-1 receptor in breast cancer. Mol. Cell. Endocrinol. 2006, 252, 241-246.

47. Mak, H.H.; Peschard, P.; Lin, T.; Naujokas, M.A.; Zuo, D.; Park, M. Oncogenic activation of the Met receptor tyrosine kinase fusion protein, Tpr-Met, involves exclusion from the endocytic degradative pathway. Oncogene 2007, 26, 7213-7221.

48. Barginear, M.F.; Bradley, T.; Shapira, I.; Budman, D.R. Implications of applied research for prognosis and therapy of breast cancer. Crit. Rev. Oncol. Hematol. 2008, 65, 223-234.

49. Happerfield, L.C.; Miles, D.W.; Barnes, D.M.; Thomsen, L.L.; Smith, P.; Hanby, A. The localization of the insulin-like growth factor receptor 1 (IGFR-1) in benign and malignant breast tissue. J. Pathol. 1997, 183, 412-417.

50. Peyrat, J.P.; Bonneterre, J. Type 1 IGF receptor in human breast diseases. Breast Cancer Res. Treat. 1992, 22, 59-67.

51. Papa, V.; Russo, P.; Gliozzo, B.; Goldfine, I.D.; Vigneri, R.; Pezzino, V. An intact and functional soluble form of the insulin receptor is secreted by cultured cells. Endocrinology 1993, 133, 1369-1376.

52. Yee, D. The insulin-like growth factor system as a target in breast cancer. Breast Cancer Res. Treat. 1994, 32, 85-95.

53. Turner, B.C.; Haffty, B.G.; Narayanan, L.; Yuan, J.; Havre, P.A.; Gumbs, A.A.; Kaplan, L.; Burgaud, J.-L.; Carter, D.; Baserga, R.; Glazer, P.M. Insulin-like growth factor-I receptor overexpression mediates cellular radioresistance and local breast cancer recurrence after lumpectomy and radiation. Cancer Res. 1997, 57, 3079-3083.

54. Lee, A.V.; Hilsenbeck, S.G.; Yee, D. IGF system components as prognostic markers in breast cancer. Breast Cancer Res. Treat. 1998, 47, 295-302.

55. Karnieli, E.; Werner, H.; Rauscher, F.J., III; Benjamin, L.E.; LeRoith, D. The IGF-I receptor gene promoter is a molecular target for the Ewings' sarcoma-Wilms' tumor 1 fusion protein. J. Biol. Chem. 1996, 271, 19304-19309.

56. Bentov, I.; Narla, G.; Schayek, H.; Akita, K.; Plymate, S.R.; LeRoith, D.; Friedman, S.L.; Werner, H. Insulin-like growth factor-i regulates Kruppel-like factor-6 gene expression in a p53-dependent manner. Endocrinology 2008, 149, 1890-1897.

57. Shahrabani-Gargir, L.; Pandita, T.K.; Werner, H. Ataxia-telangiectasia mutated gene controls insulin-like growth factor I receptor gene expression in a deoxyribonucleic acid damage response pathway via mechanisms involving zinc-finger transcription factors Sp1 and WT1. Endocrinology 2004, 145, 5679-5687.

58. Werner, H.; Roberts, C.T., Jr. The IGF-I receptor gene: a molecular target for disrupted transcription factors. Genes Chromosomes Cancer 2003, 36, 113-120.

59. Kadonaga, J.T.; Tjian, R. Affinity purification of sequence-specific DNA binding proteins. Proc. Natl. Acad. Sci. USA 1986, 83, 5889-5893. 
60. Maor, S.; Yosepovich, A.; Papa, M.Z.; Yarden, R.I.; Mayer, D.; Friedman, E.; Werner, H. Elevated insulin-like growth factor-I receptor (IGF-IR) levels in primary breast tumors associated with BRCA1 mutations. Cancer Lett. 2007, 257, 236-243.

(C) 2010 by the authors; licensee Molecular Diversity Preservation International, Basel, Switzerland. This article is an open-access article distributed under the terms and conditions of the Creative Commons Attribution license (http://creativecommons.org/licenses/by/3.0/). 